\title{
28. NORTH ATLANTIC AND MEDITERRANEAN MESOZOIC FACIES: A COMPARISON
}

\author{
Daniel Bernoulli, Geological Institute of the University Basel, Switzerland
}

\section{INTRODUCTION}

The Mesozoic sequences of the western North Atlantic, investigated on Leg 11 of the Deep Sea Drilling Project (Figure 1) resemble in many respects more or less coeval rocks of the Tethyan Mesozoic, now exposed in the mountain ranges around the present-day Mediterranean Sea. This finding is not completely unexpected. During the last decade, geophysical and oceanographic investigations have fundamentally altered our concepts of "geosynclines" and mountain building. Especially during the last few years an increasing amount of evidence has been collected indicating that Alpine-type mountain ranges might have originated from the deformation of continental margins and ocean basins (e.g., Laubscher, 1969, Dewey and Bird, 1970) rather than from narrow, elongated "geosynclinal" belts; the concepts of the new global tectonics (sea-floor spreading, plate tectonics) require the disappearance of much larger areas in tectonic sinks than formerly believed. In this context, this paper attempts a comparison of the sedimentary development of the Mesozoic sequences investigated on Leg 11 (Lancelot, this volume) with that of certain Mesozoic formations of the southern Tethyan realm, and offers a plea for an actualistic concept for the paleotectonic evolution of the Tethyan Ocean.

It is clear, however, that such a comparison has its limitations. Though the Jurassic-Cretaceous sequences of both regions reflect a similar sedimentary and bathymetric evolution, they occur in neighboring but definitely different tectonic settings that have undergone considerable subsidence during the Mesozoic. The Ammonitico Rosso and associated sediments of the southern Tethys have been deposited on sunkeil Triassic-Lower Jurassic carbonate platforms of a subsiding continental margin, whereas most of the sediments recovered during Leg 11 have been laid down on an oceanic volcanic basement. On the other hand the Jurassic sediments associated with oceanic basement rocks in the Mediterranean mountain belts are of a different facies (mainly radiolarites). Nevertheless, such a comparison may be interesting for different reasons: 1. The western North Atlantic basin has not been deformed by orogenic processes, and its sediments have not been stripped from the basement on which they have been deposited. The reconstruction of the paleotectonic and sedimentary history of the western North Atlantic continental margin and adjacent ocean basin may therefore be of great value in the construction of

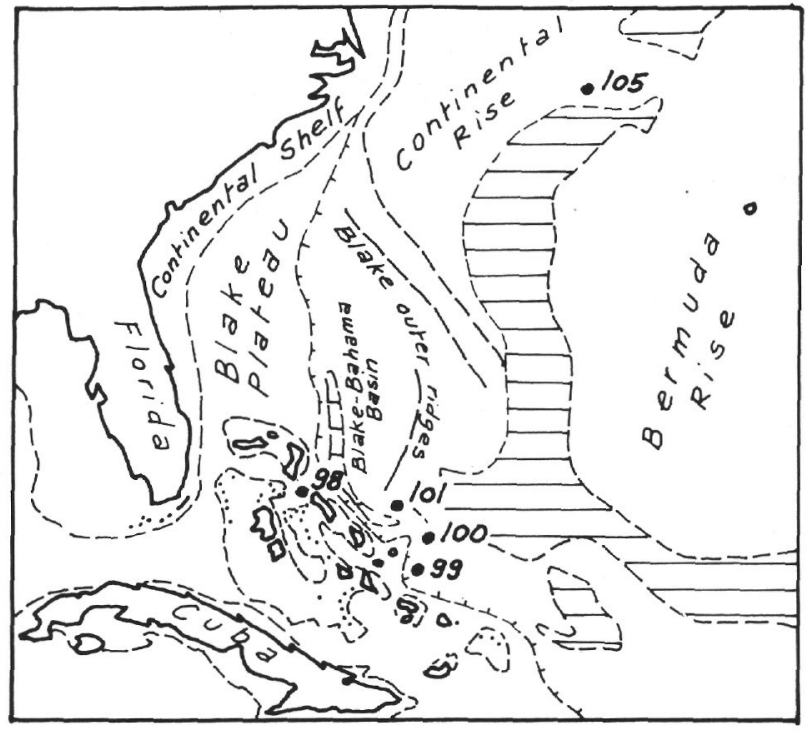

Figure 1. Location of Sites $98-101$ and 105.

actualistic models for the Mesozoic paleogeographic evolution of the Tethyan Ocean and its continental margins. Furthermore the sediments of the western North Atlantic basin have not suffered from late diagenetic processes or tectonic deformation, and this will, in many cases, lead to a better understanding of the diagenetiic history of deeper marine sediments now exposed in orogenic belts. 2. All direct information on the sediments recovered during the Deep Sea Drilling Project comes from cores only about 5 centimeters in diameter, and it is sometimes rather difficult to recognize larger sedimentary structures; at this scale large complexes of slumped beds as figured in Plate 2 can be distinguished from normally deposited sediments only by their internal structures. In such cases, comparison with Mesozoic outcrops-where large sedimentary structures can be mapped over hundreds of meters and where the stratigraphic frame is well known-may be of great help in recognizing depositional processes and reconstructing the depositional environments.

\section{ACKNOWLEDGEMENTS AND LIMITATIONS}

The present preliminary paper is based on a rapid visual examination of all Mesozoic cores of Holes 98, 99A, $100,101 \mathrm{~A}$ and 105 at Lamont-Doherty Geological Observatory and on the study of a number of selected samples that were investigated mainly by means of 
thin-sections and Stereoscan electron microscopy. Emphasis was placed on the illustration of sedimentary and diagenetic structures; due to the short time available, no detailed mineralogical examinations have been made and only preliminary data from the shipboard investigations, made available by Y. Lancelot, could be used.

I am very much indebted to the Deep Sea Drilling Project and especially to J. Ewing and C. B. Hollister for offering the opportunity to work on the cores at Lamont-Doherty Geological Observatory. I also would like to thank Y. Lancelot and H. P. Luterbacher for continuous help and lively discussions on problems of sedimentation and environmental interpretation.

The studies on Mesozoic facies of the central Mediterranean area are part of a research program on the sedimentary and paleotectonic evolution of the southern Tethys at the Geological Institute of Basel University. Support of this program by the Swiss National Science Foundation (Grant 5112.2) is gratefully acknowledged. I am grateful to H. P. Luterbacher and H. C. Jenkyns for much information and stimulating discussion during all phases of this program.

I would also like to thank F. Allemann, L. Hottinger, H. P. Luterbacher, O. Renz and M. Reichel for the determination of various fossils and V. Trommsdorff for some X-ray-diffractometer analysis.

Bataafse Internationale Petroleum Maatschappij N.V., the Hague, Holland, released some samples, collected by the author while employed at this company.

Thanks are also due to Ciba-Geigy Ltd., Basel, for use of their Stereoscan electron-microscope and to C. Brücher for her assistance. W. Sutter, C. Kapellos and A. Wyss prepared most of the photographs.

\section{GEOLOGICAL SETTING OF THE CENTRAL MEDITERRANEAN MESOZOIC SEQUENCES}

The reconstruction of the paleogeographic history of the central Mediterranean area still meets with considerable difficulties and the palinspastic rearrangement of the different tectonic units is often hampered by the complexity of the orogenic movements. Major uncertainties arise from the still uncertain original position of several tectonic units (for example, Lagonegro zone and Calabrian basement nappes in the Southern Apennines), from the postorogenic foundering of large parts of the Alpine nappe edifice (Tyrrhenian Sea, Pannonian plain) and from the erosion of whole tectonic units. However, on the evidence of paleogeographic evolution and present tectonic relations essentially three large, Mesozoic paleotectonic units can be distinguished (Laubscher, 1969, Figure 1):

1. The oceanic part of the Tethyan Sea: the ophiolite zones.

2. The southern continental margin of the Tethyan Sea, represented by the external zones of the Apennines, Dinarids and Hellenids, the Southern Alps, the Austro-Alpine thrust sheets (and the internal Carpathians).

3. The northern continental margin of the Tethyan Sea, represented by the Helvetic and Ultrahelvetic zones of the Alps. This northern continental margin and the transitional units to the south of it, that is, the possibly oceanic northpennine basin and the middle pennine Brianconnais swell are not further considered here.

The present distribution of these elements is illustrated in Figure 2. In Figure 3 a more detailed paleogeographic interpretation for the Upper Jurassic is given. In both maps no palinspastic rearrangement of the different zones has been attempted, as detailed kinematic analysis exists only for parts of the region and for the younger Alpine movements (Laubscher, 1970, 1971 , in press).

\section{The Tethyan Ocean: The Ophiolite Zones}

Of primary importance for the interpretation of the pre-orogenic history of the Mediterranean orogens is the interpretation of the ophiolite zones. These include associations of coarse, abyssal ultrabasic to basic rocks (peridotites, pyroxenites, gabbros), as well as volcanic members (spilites, pillow-lavas). The extrusive rocks are commonly associated with radiolarian cherts, pelagic shales and marls, volcanic sandstones and greywackes. In the Dinarids and Hellenids, these ophiolite complexes overlie Mesozoic (mainly Triassic) carbonate rocks, resting on Hercynian folded metamorphic basement. Until a few years ago, the ophiolite assemblages of the Hellenids have been interpreted as the product of one "catastrophic" event, that is, the extrusion of a giant mass of ultrabasic magma on the sea floor (Aubouin, 1959, 1961; Brunn, 1956). However, recent investigations have shown, that the ophiolite masses of the Eastern Mediterranean region (Dinarids, Hellenids, Turkey) have been emplaced by tectonic processes during Alpine orogeny (Bortolotti et al., 1969). Recognition that ophiolites resemble oceanic crustal rocks (Hess, 1962) leads then to the hypotheses that the ophiolites represent slices of the oceanic crust of mesozoic ocean overthrust on the more external units of the orogen (Laubscher, 1969; Decandia and Elter, 1969). Since the oceanic rocks of the ophiolite suite are only overlain by Jurassic or younger rocks, it seems 


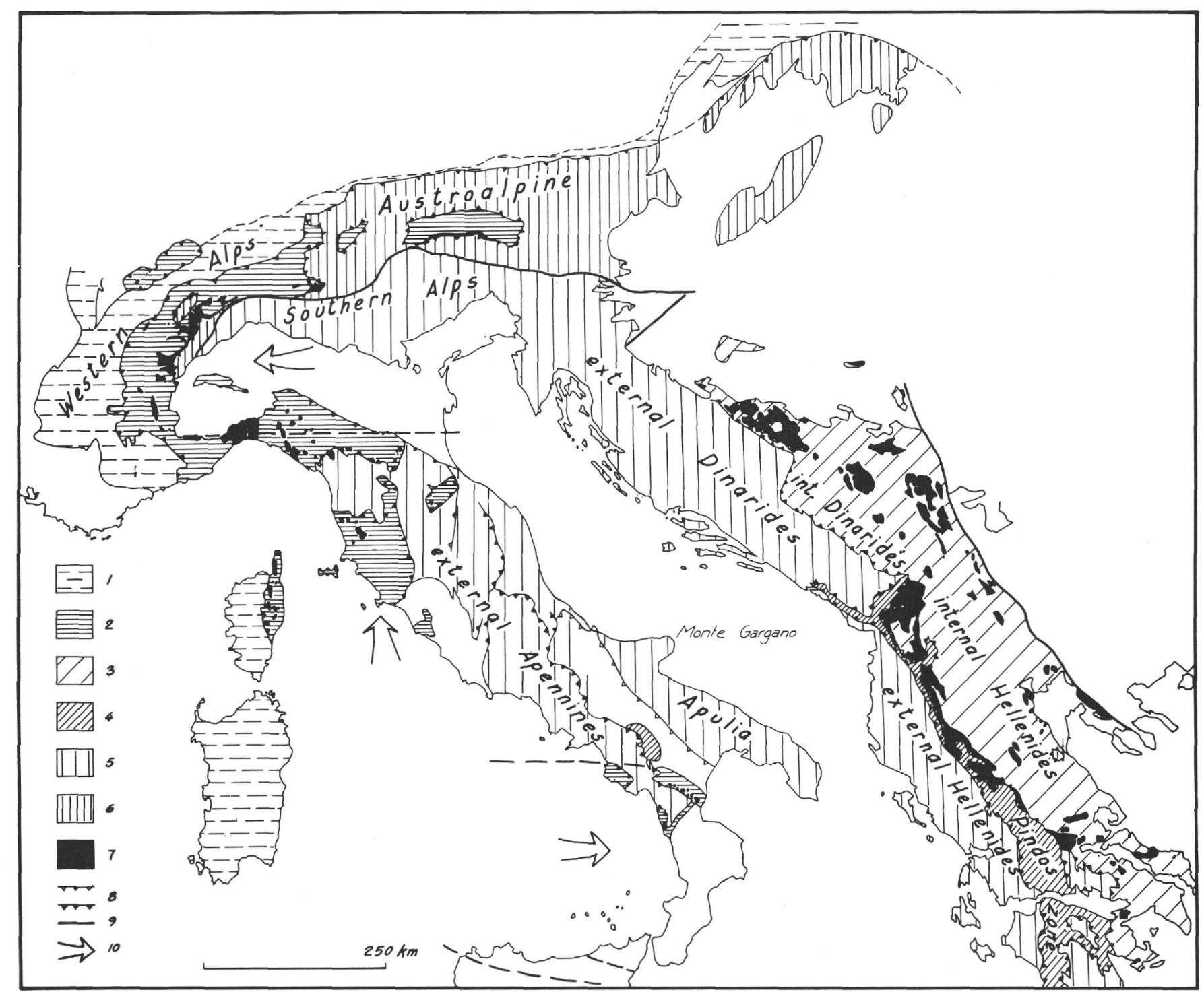

Figure 2. Schematic tectonic map of the central Mediterranean area, mainly after Laubscher (1971, in press). 1: Alpine tectonic units of the northern continental margin of the Tethys: Helvetic, Ultrahelvetic zones, Chaines subalpines, Jura Mountains, Sardinia, Corsica. 2: Pennine and Ligurian nappes, including elements of the north Pennine basin and the Brianconnais ridge. 3: Internal zones of the Dinarids and Hellenids. 4: Pindos and Lagonegro zones: Upper Triassic-Cretaceous pelagic basins with unknown basement. 5: Alpine tectonic units of the southern continental margin of the Tethys with a general "southern" vergency: external zones of Dinarids, Hellenids and Appennines; Southern Alps, Istria, Apulia. 6: Alpine tectonic units of the southern continental margin of the Tethys with a northern vergency: Austro-Alpine nappes, Transdanubian Mountains, internal Carpathians. 7: Ophiolites of the central Tethys. 8: Overthrusts. 9: Deep fracture zones, strike-slip-faults. 10: General direction of Neogene strike-slip movements. 


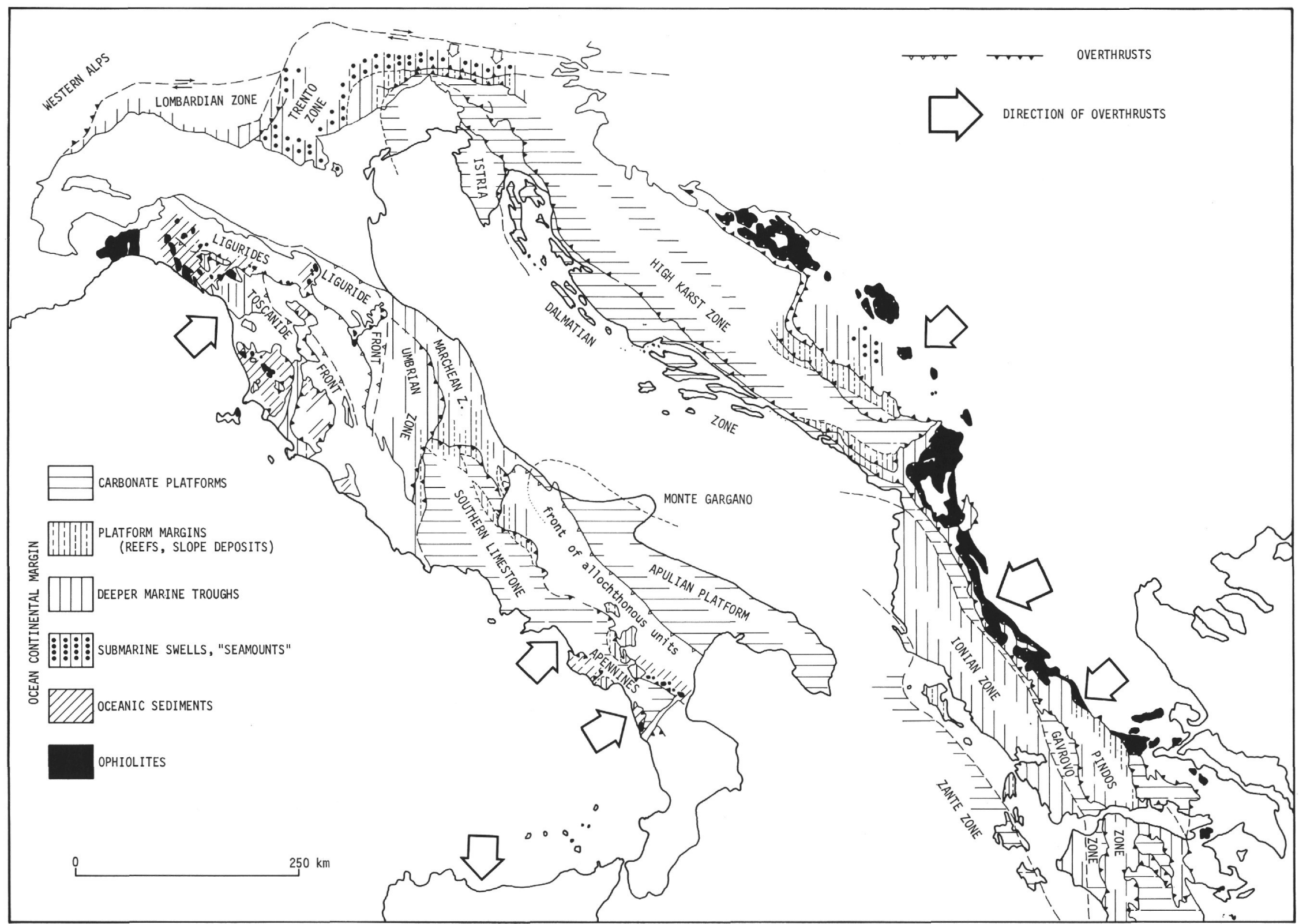

Figure 3. Alpine tectonic units and Upper Jurassic paleogeography in the Central Mediterranean area. 
that this ocean originated during the Jurassic, most probably by spreading (for details see Laubscher, 1970).

The ophiolite zone can be followed from Turkey through the Hellenids and the Dinarids to the region of Zagreb, where it is offset by an early Alpine dextral strike-slip-fault (Laubscher, 1971). From Turkey to Zagreb the ophiolites form the uppermost unit of the nappe pile thrust with a southern trend on the more external tectonic units (Brunn et al., in press). In the internal zones, the emplacement of the ophiolite nappe took place as early as late Early Cretaceous, and in the more external zones during the Late Eocene (emplacement of ophiolites on Pindos zone in Greece). Northwest of the Zagreb Line the ophiolites (southern Pennine nappes) are thrust toward the north onto the northern continental margin of the Tethys; they are in turn covered by the Austro-Alpine thrust-sheets which are derived from the southern continental margin of the Tethys (Figure 1; for the complex kinematics see Laubscher, 1971).

The ophiolites of the Northern Apennines are separated from the Pennine ophiolites of the Western Alps by an old sinistral strike-slip-fault. As in the Dinarids the ophiolites occur in the highest structural units with an eastern trend (Liguride nappes).

The transition zone between the ophiolite zone and the southern continental margin is often characterized by a unit composed of pelagic sediments, greywackes and basic extrusives (Diabas-Chert-Formation), the stratigraphy of which, however, is still poorly known.

\section{The Southern Continental Margin of the Tethyan Ocean}

The interpretation of the Austro-Alpine nappes and of the external zones of the peri-Adriatic orogens as the southern continental margin of the Tethys is derived from their original southern (in the Apennines eastern) position, the nature of their crystalline basement, and their preorogenic sedimentary evolution which closely resembles that of Atlantic-type continental margins. Part of this continental margin has not been affected by decollement and folding but only by slight tilting and late to post-orogenic faulting (Apulian platform); however, most of the continental margin has been affected by thrusting during different phases of the Alpine orogeny.

In the originally southernmost zones of the periAdriatic mountain chains, sedimentary cover-nappes and folded belts occur that have been sheared off along Upper Triassic evaporite sequences (for example, Dalmatian zone, Ionian zone, Umbrian zone, Southern Limestone Apennines), and no outcrops of crystalline basement rocks are known. However, the sedimentary evolution is almost identical with somewhat more internal zones where Hercynian folded metamorphics and granitic intrusions (Durmitor zone, Southern Alps, Austro-Alpine thrust sheets) or at least late Paleozoic clastics (Toscanides, High Karst zone) are present.

During the Permian, the Hercynian continental crust was affected by block-faulting, granitic intrusions and intense volcanic activity, and clastic sediments accumulated in graben-like depressions. Later, strong subsidence is documented by thick carbonate sequences associated with basic to intermediate volcanics of Middle Triassic age, that might be related to early phases of rifting. However, the facies distribution of the Alpine Middle Triassic shows a rather irregular pattern, and only during the Late Triassic did extensive deeper marine basins develop in the Pindos zone of the Hellenids, in the southern Apennines (Lagonegro zone) and in Sicily (Sclafani zone). These basins existed throughout the Mesozoic; however, it is difficult to say if they were floored by oceanic crust formed during early phases of rifting, or by foundered continental crust, as no pre-Middle Triassic sediments occur except for Paleozoic olistoliths.

By the latest Triassic, most of the southern continental margin of the Tethys was covered by an extensive carbonate shelf on which thick sequences of shallow water carbonates and evaporites were deposited. During the Early Jurassic, the continental margin was affected by conspicuous block-faulting and differential vertical movements occurred with displacements of up to 4000 meters along normal faults (Lugano Line: D. Bernoulli, 1964). In the external zones of the periAdriatic mountains there is hardly any volcanic activity connected with these movements, though metamorphic events of Liassic age, in the deeper crust of the Southern Alps might be related to them (Laubscher, 1970). Most probably the tensional tectonic movements and the increased subsidence during the Early Jurassic are closely related to phases of active rifting in the oceanic realm, that is, in the ophiolite zone.

As a consequence of faulting and differential subsidence deposition of shallow water sediments continued only in a number of Bahamian-type carbonate platforms separated by deeper troughs, comparable to the Florida Straits or the Tongue of the Ocean. On the platforms, subsidence was balanced by prolific carbonate production and sedimentation, while in the troughs fine-grained pelagic sediments and carbonate turbidites, originating from the adjacent platforms, were deposited. Large parts of the former carbonate shelf were drowned to bathyal depth during the Jurassic, and conditions were comparable to the ones on the Late Cretaceous or Early Tertiary Blake Plateau. In these realms local swells and basins occurred, that, at least during their early history, were structurally 
controlled and had an individual tectonic and environmental history. On the swells, thin pelagic limestone sequences are found that are characterized by condensed faunal successions, early lithification and hardgrounds, and tectonic fissures filled with unconsolidated sediments. The sedimentary sequence, passing from pelletal limestones and crinoidal calcarenites to skeletal limestones with pelagic lamellibranchs and coccolith limestones, indicates, in most cases, a general deepening of the swells (cf. Jenkyns and Torrens, 1971). In the local basins small amounts of terrigeneous clays were trapped; and, mainly pelagic limestones, marls, siliceous rocks and redeposited pelagic material, derived from the top and flanks of the highs, accumulated. From the Late Tithonian onwards more even subsidence and increased carbonate supply tended to bury the submarine highs and to eliminate abrupt facies changes. It is in this setting that the Ammonitico Rosso and the other pelagic facies, which compare best with the North Atlantic sediments, are found.

The stratigraphic frame of the different pelagic formations of the southern Tethys and of their facies equivalents from the western North Atlantic, as well as, their gross lithologic development has been summarized in Figures 4 and 5.

\section{Alpine Orogenic Movements}

In the central Mediterranean area, Alpine orogenic movements took place as early as the Early Cretaceous, and at places possibly even earlier (Mercier, 1966). In the internal Hellenids and Dinarids, the emplacement of the ophiolite nappe took place in pre-Albian times as shown by the transgression of shallow-water limestones on the nappe structure (cf. Aubouin, 1959 etc.; Brunn, 1956). Such movements are corroborated by Lower Cretaceous flysch sediments in the slightly more external zones (Blanchet et al., 1970). In the Eastern Alps pre-Cenomanian tectonic movements in the ophiolite zone are followed by Upper Cretaceous flysch sediments containing ophiolite detritus. As these flysch sediments occur in the lowermost originally northern Austro-Alpine units and in the southern Pennine realm, the movements seem to be connected to the boundary between the continental margin and the oceanic realm and most probably had a southern verge (Laubscher, 1970). The more external zones of the peri-Adriatic mountain chains were not affected by these movements. In the Apennines Cretaceous movements at the boundary between the Liguride/Toscanide realms are difficult to prove, however, they cannot be excluded; and possibly Section 2 in Figure 6 has to be altered drastically for the Upper Cretaceous at the ocean/continental-margin boundary.

The main nappe movements in the internal parts of the Hellenids Dinarids and central Alps took place during the Early Tertiary (Paleocene-Eocene) (Laubscher, 1970; Trümpy, in press). They were followed by thermal events, uplift and molasse sedimentation in the foreland. Early Tertiary movements in the Ligurids (Paleo-Apennines) are documented by Lower Oligocene clastics that show both flysch and molasse characteristics. Neogene nappe movements, from Burdigalian to Lower Pliocene, occurred in the external zones of the peri-Adriatic orogens, the Southern Alps and in the Helvetic realm north of the Lower Tertiary Alps. Superposed on these movements are large-scale strike-slip movements that largely determined the arcuate shape of the western Alps and the Apennines. Partly these movements are followed by isostatic uplift (Alps), partly by post-orogenic down-faulting (Tyrrhenian basin, Aegean Sea) during the Pliocene and Quaternary, however, compressional movements might still continue on the outer margins of the Apennines and Hellenids.

\section{COMPARISON OF NORTH ATLANTIC AND MEDITERRANEAN MESOZOIC FACIES}

\section{Ammonitico Rosso and Associated Sediments Versus Upper Jurassic of Western North Atlantic}

In the Alpine-Mediterranean Jurassic various types of pelagic sediments have been called Ammonitico Rosso. Originally, the term has been used for red, nodular limestones, rich in ammonites, of Middle and Upper Jurassic age occurring in the region of Verona (Southern Alps). These limestones are characterized by submarine dissolution features, hard-grounds, early lithification and condensed faunas and are a typical swell facies (Hollmann, 1964; Sturani, 1964; cf. Garrison and Fischer, 1969). Later the term has been extended to Toarcian-Aalenian red, green or gray, nodular marly limestones and marls that occur in the western part of the Southern Alps, the Central Apennines and Western Greece. As shown by the intercalations of slumped complexes and turbidites this formation is essentially basinal (Bernoulli, 1964, 1971), and the nodular character of the rocks is not due to submarine carbonate solution on the sediment surface, but to a number of different processes. As emphasized by Aubouin (1964) both facies types occur in different paleotectonic settings, however, transitional facies types may occur.

In the Southern Alps, the central Apennines and in western Greece, the term Ammonitico Rosso has been used as a formational name, both for the Middle and Upper Jurassic limestone and for the Toarcian-Aalenian marls; further confusion in stratigraphic terminology has arisen from the fact that similar facies of entirely different ages occur in other parts of the Mediterranean region (cf. Aubouin 1964; Garrison and Fischer 1969; 


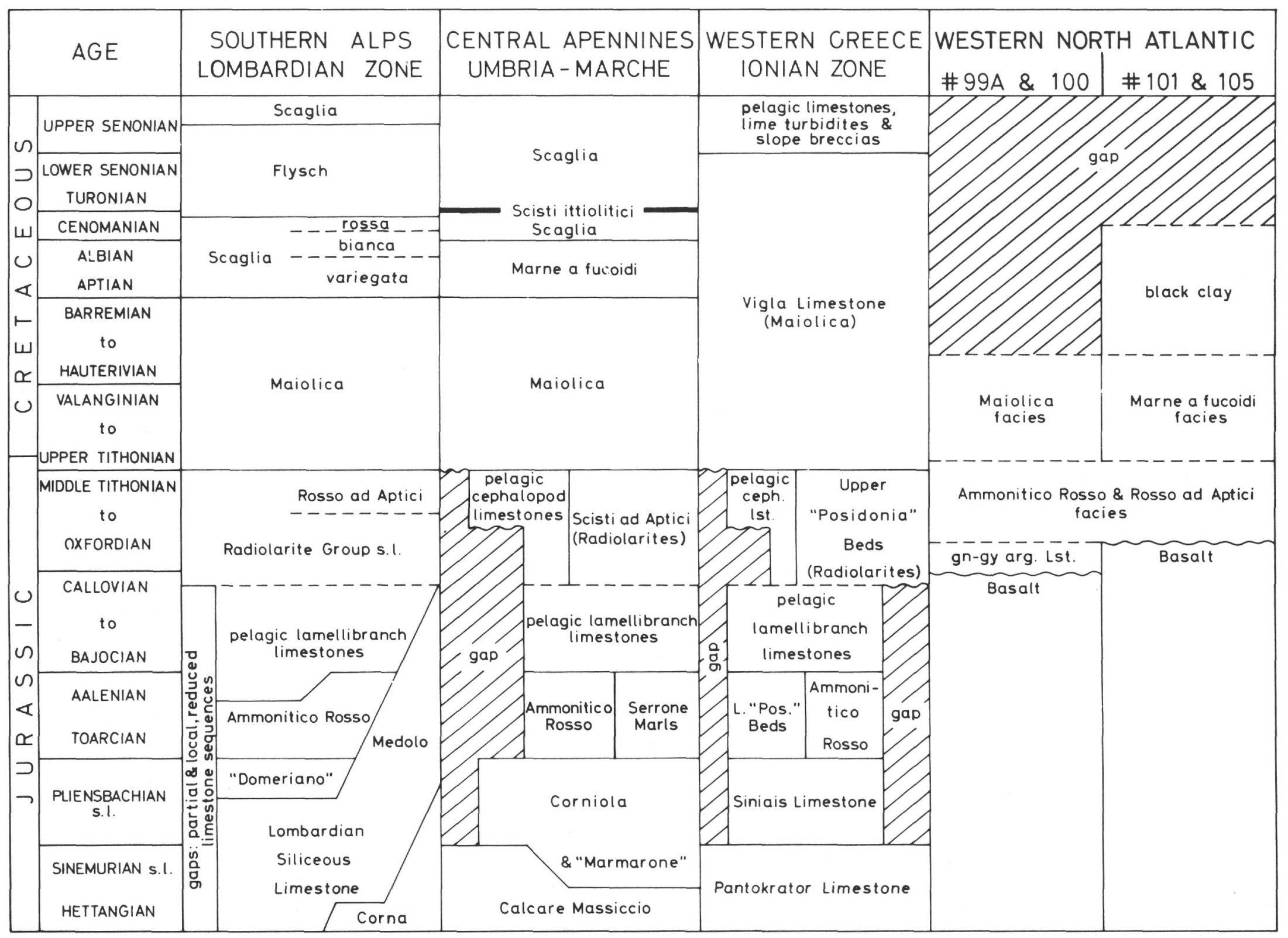

Figure 4. Simplified stratigraphic scheme of some Jurassic-Cretaceous sequences in the Central Mediterranean area and their facies equivalents in the western North Atlantic Basin. 


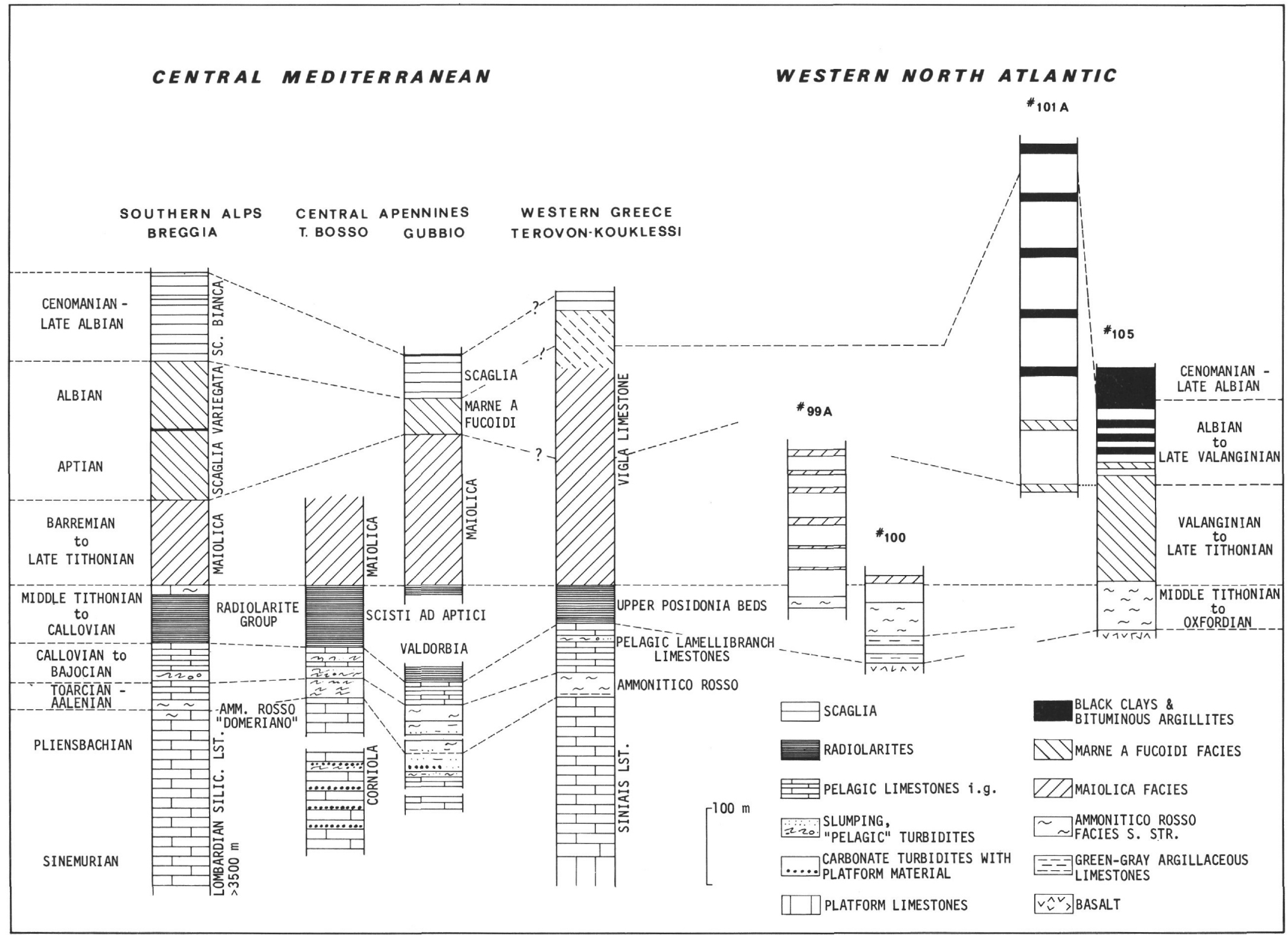

Figure 5. Comparison of some Jurassic-Cretaceous sequences of the Central Mediterranean area and of the western North Atlantic Basin. 
\begin{tabular}{lll} 
1. Florida & $\begin{array}{l}\text { Blake- } \\
\text { shelfinental }\end{array}$ & $\begin{array}{l}\text { Bahama } \\
\text { Basin }\end{array}$ \\
\hline
\end{tabular}

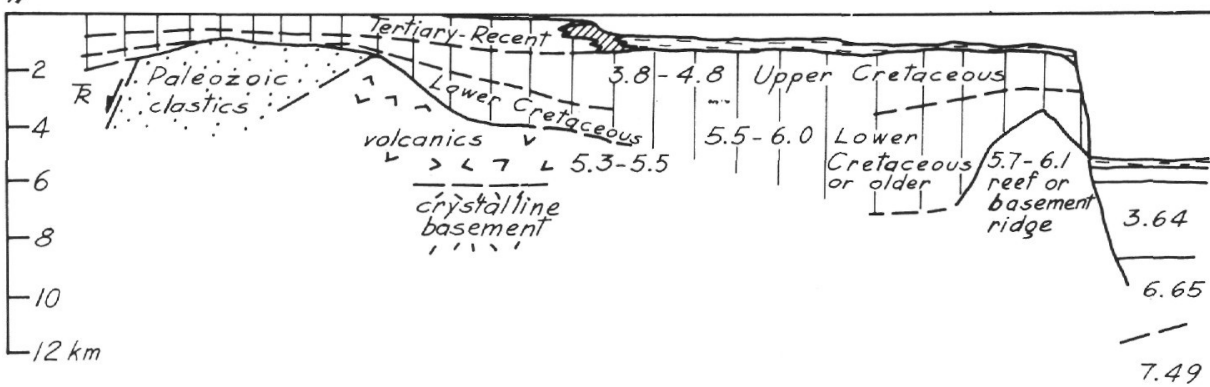

2

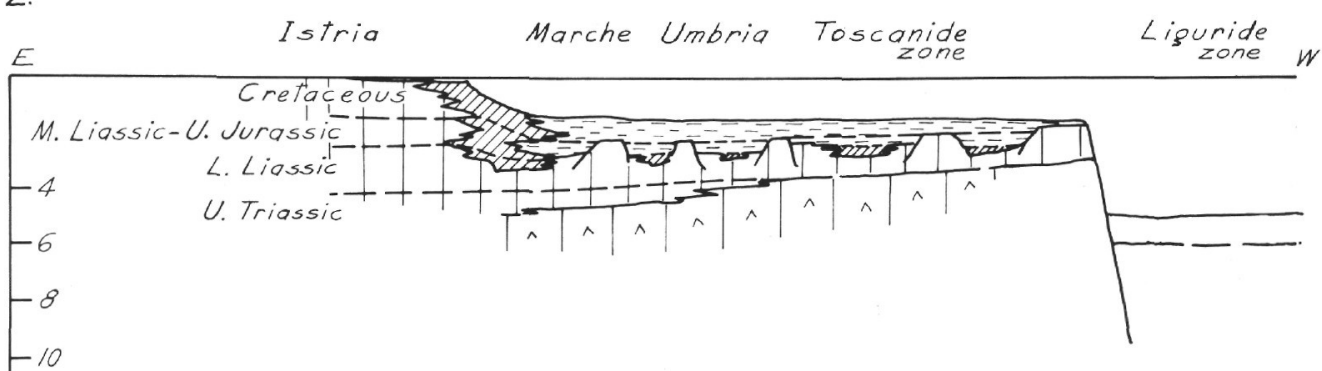

$-12 \mathrm{~km}$

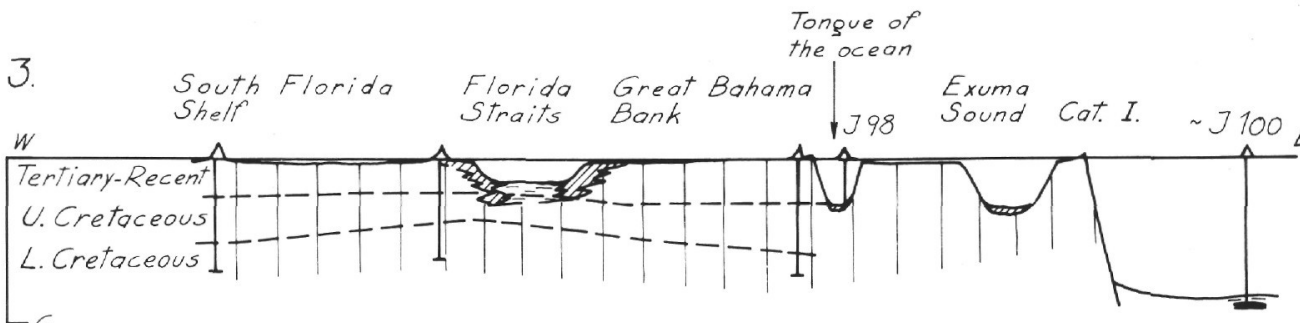

$-6$

$-8$

$-10$

$-12 \mathrm{~km}$

4.

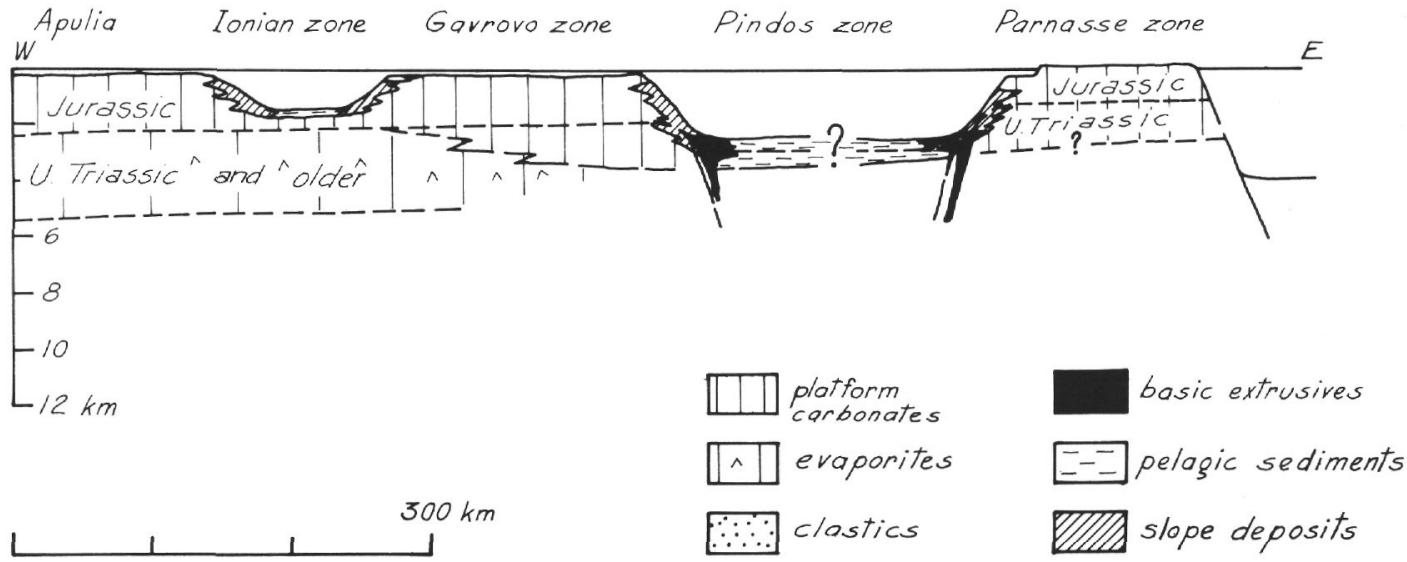

Figure 6. Comparison of Recent continental margins of Atlantic type with continental margins of the Mesozoic Tethys. North American continental margin after Sheridan et al. (1966). 
Bernoulli and Jenkyns 1970). In this paper we refer exclusively to the Toarcian-Aalenian varicolored, nodular, ammonite-rich marls and limestones of the basinal successions with which the Upper Jurassic of the western North Atlantic basin shows most analogies.

\section{Stratigraphic and Paleogeographic Frame}

The stratigraphic frame and the general lithological sequence of the Ammonitico Rosso and the other pelagic formations has been given in Figures 4 and 5. In the Umbrian-Marchean Apennines and western Greece, the pelagic sequences overlie carbonate platform deposits of Early to locally Middle Liassic age. In the western Southern Alps, pelagic sedimentation had already started during the lowermost Liassic (Lombardian Siliceous Limestone, Hettangian-Lower Pliensbachian), and shallow, open marine limestones were only deposited in limited areas during that time.

In Marche-Umbria and western Greece, the Late Sinemurian to Pliensbachian basinal deposits consist of light gray to yellow calcilutites with sponge spicules, Radiolaria, and lenses and bands of replacement chert (Corniola Formation, Siniais Limestone). In MarcheUmbria, slump conglomerates, fluxoturbidites and proximal turbidites (Marmarone) containing redeposited carbonate platform material indicate local persistence of the carbonate platforms during the Upper Sinemurian and part of the Pliensbachian. Locally, red nodular limestones with ammonites of the Upper Pliensbachian occur. During the ToarcianAalenian two different groups of facies occur: 1. A more basinal facies that in western Greece comprises siliceous argillites and bedded cherts, containing pelagic lamellibranchs (Lower Posidonia Beds). In MarcheUmbria gray marls with interbedded slumped bed, graded calcarenites and calcisiltites (Serrone Marls, Colacicchi et al., 1970) are present; similar rock types occur in the Southern Alps. 2. Red and greenish-gray nodular marls and marly limestones, rich in ammonites, with intercalated slumped beds and pelagic turbidites: this is the typical Ammonitico Rosso Formation. As slumped complexes of this formation occur in the Lower Posidonia Beds (Bernoulli, 1971) and in the Serrone Marls (Colacicchi et al., 1970), this facies seems to occur in a somewhat higher position. Most of the Middle Jurassic is represented by well-bedded limestones, containing only rare ammonite faunas, but numerous pelagic lamellibranchs and Radiolaria (pelagic lamellibranch limestones). In the Upper Jurassic, fine-grained pelagic limestones with lenses and nodules of chert, bedded radiolarites and siliceous argillites are present (Radiolarite Group, Scisti ad Aptici, Upper Posidonia Beds). In the upper part of this formation, red nodular limestones with beds of redeposited pelagic material are locally present (Rossa ad Aptici). In the uppermost Jurassic, white calcilutites with chert reflect (Maiolica) comparatively uniform conditions of sedimentation over large parts of the central Mediterranean area.

The stratigraphically reduced sequences differ from their basinal equivalents mainly by their small thickness, the reduced clay content, the absence of cherts, and numerous stratigraphic gaps that may encompass different time intervals with, in extreme cases, the Tithonian resting directly on the Middle Liassic. In most cases, these gaps have been interpreted as results of emergence and subaerial erosion (Institut de géologie etc., 1966; Colacicchi et al., 1970), however, non-deposition and/or submarine erosion in a pelagic realm-at least from the Middle Liassic onwards-seem to explain many of the observed features in a much better way (Bernoulli, 1971). Early submarine lithification, inorganic segregations of ferruginous crusts and nodules (sometimes interpreted as algal stromatolites or oncolites, Colacicchi et al., 1970), and intraformational erosional and solution surfaces are common in the pelagic swell facies, and the sequences are cut by a complicated system of fissures, in which different generations of unconsolidated sediment of the overlying formations flowed to form complex "intrusions" and breccias. This, together with the abrupt changes of facies and thickness indicates that the reduced sequences were deposited on submarine highs that were bounded by synsedimentary normal faults ("seamounts").

The Upper Jurassic sediments of the western North Atlantic Basin present very pronounced lithological analogies with the Ammonitico Rosso Formation; however-as seen in the Plates 1 through 8-similar sedimentary structures have been found in other pelagic formations of the Mediterranean Jurassic. Faunistically, the Upper Jurassic encountered on Leg 11 corresponds best to the coeval Rosso ad Aptici.

The facies equivalents of the Ammonitico Rosso have been found at Site 99 (Hole A) from 235 to 249 meters (Cores 12, 13 and 14), at Site 100 from 237 to 280 meters (Cores 2 through 6) and at Site 105 from 559 to 624 meters (Cores 32 through 40). At Site 105 this lithology overlies basaltic rocks with a few decimeters of recrystallized limestone and graded palagonitic tuffs intercalated. At Site 100, a sequence of green to light gray, homogenous or burrowed calcilutites is present from 280 to 315 meters (Cores 7 through 10) that presents some analogies to pelagic mudstones of the Mediterranean Jurassic. The thicknesses of the corresponding formation are comparable as Figure 5 shows.

\section{Composition of the Sediment}

The sediments of the Ammonitico Rosso and their North Atlantic facies equivalents are, with the exception of redeposited sediments, very fine grained 
throughout; they are composed of various mixtures of clay minerals and calcitic material. The calciumcarbonate content is extremely variable and ranges in the Mediterranean Ammonitico Rosso from 50 per cent to 70 per cent in the marls and up to 95 per cent in the limestones (Hallam, 1967). Similar estimates with some lower values have been made for the North Atlantic sediments during shipboard investigations.

Very little is known on the composition of the clay fraction; as far as it has been investigated, it seems to be composed entirely of illite and some hematite, with a trace of kaolinite present in sediments of the same facies and age in the Eastern Alps (Hallam, 1967). In the Southern Alps a small admixture of some sandsized detrital quartz, mica and subordinate feldspar is present; in the central Apennines only traces of these minerals occur in the silt grades. In the equivalent sediments of the North Atlantic quartz, mica and chlorite occur as well; additionally, zeolites are present at Site 105.

In the Ammonitico Rosso, calcite occurs in the skeletons of planktonic nanno organisms and as neomorphically formed anhedral grains. In the Lower and Middle Jurassic mainly planktonic forms of unknown systematic position (identified by Fischer et al., 1967, as Thoracosphaera: by Noel, 1965, as Schizosphaerella) occur, sometimes even in rock-forming quantities (Plate 8, Figure 6; cf. Bernoulli and Jenkyns, 1970). From the Upper Liassic onwards, coccoliths get more and more important. In the cherty limestones of the Upper Jurassic, they are mostly badly preserved or completely obliterated, but the coeval limestones of the submarine swell facies contain them in abundance (Plate 8, Figure 4). In the Upper Jurassic of the North Atlantic, Stereoscan electron micrographs show them together with flakes of clay minerals and neomorphically formed calcite grains (Plate 8, Figures 1, 2, $3,4,5,7$ and 9).

\section{Fauna}

The most conspicuous fossils of the Ammonitico Rosso are the ammonites that gave the formation its name. Other megafossils are rare and only occasionally aptychi, echinoderm remains and pelagic lamellibranchs of the genus Bositra are present. The ammonites occur only as internal molds, whereas, originally calcitic remains were preserved as such. Microfossils include mainly pelagic lamellibranchs, Radiolaria that appear as calcite- or silica-filled molds, and poor faunas of foraminifera consisting mainly of primitive agglutinating forms and lagenids.

The fossil content in the North Atlantic Upper Jurassic compares much better with the one of the coeval Rosso ad Aptici of the Mediterranean region. Wellpreserved aptychi (Renz, this volume) and planktonic crinoids (Hess, this volume) are common in both formations, as well as planktonic microorganisms of unknown systematic position that include Globochaete and Stomiosphaera. Ammonites are extremely rare and only badly preserved; during Leg 11 only one poorly preserved internal mold of an Aspidoceras has been found (see Renz, this volume). The foraminiferal faunas in the North Atlantic Upper Jurassic are mainly composed of primitive arenaceous foraminifera and lagenids; as pointed out by Luterbacher (this volume), the latter are very similar to a coeval fauna described by Farinacci (1965) from a marly intercalation in the Scisti ad Aptici of the Central Apennines. From the same locality Oertli (1967) has described an ostracod fauna that in turn resembles very much the ones found in the North Atlantic Upper Jurassic (see Oertli, this volume).

Small calcite-replaced ammonites and Globigerina have only been found in clasts of indurated white limestone. These clasts have their equivalents in the limestones of the typical swell facies, to which Globigerina seems to be restricted in the south Tethyan Jurassic: it never has been found in the basinal cherty limestones or radiolarites.

\section{Sedimentary Structures}

Many of the green-gray marly lithologies in the North Atlantic Upper Jurassic, especially at Sites 99 and 100, are finely laminated and show a small-scale wavy flaser-texture. Homogenous marly mudstones with occasional burrows are present in the green-gray marly calcilutites in the lowermost section of Hole 100. Similar lithologies are observed in the green-gray lithologies of the Ammonitico Rosso.

The most conspicuous feature of the Ammonitico Rosso, however, is its nodular aspect. Many of the nodules, that consist of calcilutite (biomicrite) set in a more marly, often flaser-textured matrix, obviously originated from early, diagenetic sediment flow (Plate 5 , Figures 3 through 8 ), or represent derived clasts (Plate 5, Figure 1; Plate 6, Figures 3 and 4). In other places, the nodular aspect is related to burrows, as can be seen in calcilutites overlying carbonate turbidites in which the nodular aspect increases toward the top together with the burrow structures. In many instances, especially in the Mediterranean Ammonitico Rosso, the nodular aspect is accentuated by postdepositional intra-stratal solution (cf. Plate 6, Figure 5). Submarine dissolution phenomena (subsolution; Hollmann, 1964) on sediment surfaces, however, were not observed.

Burrowing is very common in the Ammonitico Rosso facies both in the central Mediterranean area and in the North Atlantic. Most burrows are of Chrondrites-type, but in the Southern Alps Zoophycus occurs quite frequently. 
Redeposited pelagic sediments are a typical feature in the basinal Ammonitico Rosso facies. In the Jurassic of the western North Atlantic these beds contain, except for some volcanic material, only penecontemporaneously displaced pelagic material; no sediments or fossils derived from carbonate platforms have been found. In the Tethyan Jurassic, intercalations of redeposited platform material are restricted to the areas adjacent to carbonate platforms.

The redeposited beds usually exhibit a cyclic development, ranging in extreme cases from large slumpcomplexes to graded siltites and homogenous mudstones, in many cases, however, the cycles are truncated at the top or comprise only the upper, distal parts of the genetic unit. At the base of the cycles, large slump-folded complexes occur that pass laterally and vertically into pebbly mudstones. At their top, these intervals usually show clear stratigraphic contacts indicating the non-tectonic origin of the structures. The slumped complexes and pebbly mudstones may be overlain by graded calcirudites or calcarenites that also occur independently from slumped beds (Plate 2, Figure 2; Plate 3, Figure 1). Fine calcarenites and calcisiltites are often reduced to thin pelagic shell beds intercalated in the pelagic limestones (Plate 4, Figures 1 and 5; for example, 11-105-34-5, 29 centimeters). The graded beds are often covered by apparently homogenous or faintly laminated red or gray marly calcilutites without a nodular structure and without any traces of burrowing; these intervals apparently represent the finest fraction of the turbidites and are often more than one meter thick (Plate 2, Figure 2; Plate 3, Figure 1; Plate 4, Figure 4). Sometimes they are not observably linked with graded beds; in this case they merely represent the most distal parts of turbidites.

The structures occurring in slumped complexes and pebbly mudstones have been described in quite some detail from the Tethyan Jurassic (Bernoulli, 1964, 1971; Bernoulli and Jenkyns, 1970) and some characteristic examples from both the Tethyan and the North Atlantic Jurassic are illustrated on Plates 1 to 3, and Plates 5 and 6 . In the Tethyan Jurassic, slump-folded intercalations may range in thickness from a few decimeters up to ten and more meters, and often pass laterally into slump rubble and completely retextured sediments (Plates 1 and 2; cf. Bernoulli, 1964, Figures 25-31; 1971; Garrison and Fischer, 1969, Figures 15-17; Bernoulli and Jenkyns, 1970, Plate 4). The style of deformation varies thus greatly within one and the same slump mass and ranges from brittle fracture and imbrication of limestone beds, shearing and thrusting of otherwise undeformed strata to plastic deformation without fracturing. At places large blocks of lithified pelagic limestones occur in otherwise plastically deformed rocks.
In the North Atlantic sediments plastic deformation prevails throughout. Intense deformation of unlithified sediments may produce completely retextured rocks that contain rotated and deformed limestone clasts in a fluidly textured matrix (Plate 5; further examples of this in Core 11-105-37-5). Sometimes such clasts are coated by fluidly textured mantles or entirely deformed (phacoidal texture, Voigt, 1962; see for example, 11-105-37-5, 50 to 54 centimeters). Other limestone clasts exhibit tails that merge into the fluidly textured matrix (Plate 5, Figures 3 through 8). This fluid lamination is therefore not a depositional structure but results from early diagenetic sediment flow; it may in turn be caught up into recumbent folds (Plate 5 , Figures 1 and 2). These lithologies pass continuously into pebbly mudstones that in a homogenous or fluidly textured matrix contain more or less closely packed limestone nodules (Plate 2, Figure 3; Plate 6, Figures 3 through 6). Differently orientated geopetal fabrics in such limestone nodules clearly indicate that the clasts are derived (Plate 6, Figures 3 and 4).

Displacement of clasts from distant sources is indicated by lithologies that are only encountered as pebbles in the slumped beds and pebbly mudstones. At Site 105, Cores 36 and 37 contained several clasts of white pelagic limestone, composed of calcareous nannoplankton (Plate 8, Figure 5) and containing pelagic lamellibranchs. Burrows are often dolomitized and the fabric of the rock closely resembles that of Upper Jurassic sediments from submarine highs in the Central Apennines and western Greece (Bernoulli and Renz, 1970). As is observed in the basinal sequences in Greece and Italy, it is only in such clasts that Globigerina and small calcitized ammonites occur. It is therefore suggested that these limestones were deposited on highs above the depth of dissolution of planktonic foraminifera and then transported into the local basins where planktonic foraminifera usually were destroyed, and only the more resistant lagenids and coccoliths were preserved (cf. Maxwell et al., 1970; Pimm et al., 1971).

Rock fragments of pre-existing formations, as they occur in the Tethyan basinal Jurassic, have not been found during Leg 11, however it cannot be excluded that the small palagonite fragments are derived from still exposed basement highs.

The graded beds contain various proportions of pelagic intraclasts and skeletal material. Bottom marks (flute and load casts) occur, but are generally more difficult to observe than in flysch sediments. In the lower part, the graded beds mainly contain flat, rounded pebbles of pelagic calcilutites in a more marly matrix (Plate 3 , Figure 3; Plate 4, Figures 1 and 3); in the Tethyan Jurassic these pebbles are often closely packed and their shape has been strongly modified by postdepositional pressure-solution (Plate 3, Figures 2 and 4). In the finer fractions that often show distinct currentlaminations, mainly pelagic lamellibranchs, calcitized 
Radiolaria and occasional echinoderm debris occur (Plate 3, Figures 4 through 6; Plate 4, Figures 4 and 5). Sparry calcite occurs in syntaxial replacement rims or as interparticle cement (Plate 6 Figures 1, 2 and 5, 6).

\section{Siliceous Sediments}

At Site 105 , siliceous sediments are virtually absent. The only occurrence of silicification has been found in a particular type of skeletal turbidite that is mainly composed of planktonic crinoids (Saccocoma) (Plate 7, Figure 2). Beside Saccocoma small pelagic intraclasts and microfossils occur. Sheltered cavities below larger crinoid fragments have been partly filled with large syntaxial calcite overgrowth, whereas large parts of the original sediment have been replaced by spherulitic aggregates of chalcedony, that also fill the remaining pore-space in the cavities and between the particles. A very similar lithology occurs in the coeval Rosso ad Aptici Formation of the Southern Alps (Plate 7, Figure 1).

At Site 100, different types of chert have been found. Red calcilutites with irregular bodies of replacement chert can be best compared to the cherts occurring in the Rosso ad Aptici Formation (in the ToarcianAalenian Ammonitico Rosso cherts are rare). As shown in Plate 7, Figure 4, mobilization and crystallization of silica seems to have taken place through various stages of diagenetic reorganization of silica (cf. Pimm et al., 1971). Radiolarian cherts, that resemble the radiolarites of the Alpine Jurassic, are rare (Plate 7, Figures 5 and 6). They contain silica-filled Radiolaria in a cryptocristalline, impure and somewhat calcitic siliceous matrix, that in the Alpine examples has often been converted into bands of microcrystalline quartz (cf. Pimm et al., 1971).

\section{Environment of Deposition}

The basinal Ammonitico Rosso and the Jurassic sequences of the western North Atlantic basin have been deposited in a pelagic realm; terrigenous influx is restricted to silt-sized quartz, micas and to clay minerals and seems to be related to rather distant sources. Redeposited pelagic sediments suggest a marked submarine topography with local basins and swells. In the case of the Tethyan basinal Ammonitico Rosso facies, this topography is related to the break-up and differential subsidence of a former carbonate platform and to synsedimentary block-faulting during early stages of sinking (Bernoulli, 1971). In the Central Apennines and in western Greece, it appears that the single swells and basins were rather limited and sometimes did not exceed a few or some ten kilometers across and from seismic reflection data a similar order may be inferred for the North Atlantic Jurassic. In this area, however, the irregular topography corresponds to the rugged surface of the volcanic basement, but this does not exclude synsedimentary tectonic movements occurring as well.

The peculiar facies of the Ammonitico Rosso seems to be related primarily to basin morphology and synsedimentary tectonics, and there is a wide range of possibilities for bathymetric interpretations. As the southern continental margin of the Tethys and the North American basin have both undergone considerable subsidence after deposition of the Ammonitico Rosso, the bathymetry can only be inferred from circumstantial evidence. From the faunal composition, a bathyal environment seems to be indicated (Luterbacher, this volume). As at least a few hundred meters may be assumed for the submarine highs, from which the Globigerina-bearing limestones are derived, a still greater depth must be accepted for the basinal sequences in which the planktonic foraminifera are dissolved. A lower depth limit for the depositional environment is given by the compensation depth of calcite, that, in the North Atlantic basin, has only been reached during later stages. However, as the Ammonitico Rosso and the associated sediments in the peri-Adriatic mountain chains are deposited on a continental margin underlain by continental crust, depths on the order of several thousand meters do not seem feasible for the Tethyan associations. Based on these arguments, a depositional depth of several hundred meters or at most around a thousand meters has been assumed for the Tethyan Ammonitico Rosso (Bernoulli, 1971), and similar or perhaps somewhat higher values might be accepted as a working hypothesis for the western North Atlantic

\section{Maiolica versus Upper Tithonian-Lower Cretaceous at Sites 99 and 100}

In the uppermost Jurassic and Lower Cretaceous, white, almost pure and very fine-grained limestones, rich in calpionellids and chert nodules, are widespread in the Tethyan region. This pelagic facies has been given different names of which Maiolica-used both in the Southern Alps and in the Apennines-is probably the best known and is used here; synonymous names are for example Biancona (Venetian Alps), Lattimusa (Sicily), Calcare Rupestre (Umbrian-Marchean Apennines) and Vigla Limestone (western Greece). The Maiolica facies occurs in different paleotectonic settings: in the internal zones of the northern Apennines it rests on radiolarites that in turn overlie oceanic basement rocks (pillow lavas, ophicalcites, serpentinites etc.); whereas, in the external zones of the periAdriatic mountain ranges these sediments have been laid down on the pelagic cover of sunken carbonate platforms of the southern continental margin.

In the external zones of the peri-Adriatic mountain ranges, the Maiolica Formation is composed of wellbedded, mostly white, sometimes light gray to slightly 
yellow calcilutites which are rich in bands and nodules of black, gray or yellowish replacement chert (Plate 11, Figure 2). Bedding is mostly in the order of one to some decimeters and in the uppermost part of the formation, thin intercalations of dark gray to black marls are present. Intercalations of slumped beds and lime turbidites with displaced neritic material are bound to zones adjacent to carbonate platforms.

The lower boundary of Maiolica seems to be synchronous over most of the peri-Adriatic region coinciding with a major facies change in the pelagic environment and with the first appearance of Late Tithonian calpionellid associations. Where the Marne a Fucoidi and Scaglia Variegata are overlying the Maiolica, the upper boundary is probably synchronous as well and coincides more or less with the Barremian-Aptian boundary. The thickness of the formation is mostly of the order of 250 to 350 meters, but in extreme cases (western Greece) it varies from less than 100 meters to 500 meters and more (Institut de Géologie etc., 1966).

Sediments corresponding to the Maiolica facies have been encountered in Hole 99A from 44 to 203 meters (Cores 3 through 11) and in Hole 100 from 203 to 212 meters (Core 1). The same formation has already been found during Leg 1 at Sites 4 (250 meters, Core 5) and 5 (230 to 274 meters, Cores 5, 6 and 7), and has also been compared to synchronous facies in the Mediterranean region (Oberalm Beds, Maiolica, Biancone; $\mathrm{M}$. Ewing et al., 1969, p. 232). In contrast to the Maiolica, the North Atlantic sediments are not, or are only slightly, lithified.

\section{Composition of the Sediment}

The fine sediment in the Upper Tithonian-Lower Cretaceous calcilutites at Sites 99 and 100, is almost entirely composed of calcarous nannoplankton (Plate 10, Figure 8; Plate 11, Figures 9 and 10) and accordingly the calcium-carbonate content is very high. The composition of the Maiolica limestones seems to have been very similar; however, the original fabric has been largely altered by diagenetic processes and much neomorphically formed calcite is present (Plate 10, Figure 7; Plate 11, Figure 11, cf. Grunau, 1959; Farinacci, 1964; Garrison, 1967; Fischer et al., 1967). With an exception made for the marly intercalations near the boundary with the Marne a Fucoidi and the Scaglia Variegata, the calcium-carbonate content is equally high. For the early diagenetic replacement cherts see below.

\section{Fauna}

The faunal composition of the Upper Tithonian-Lower Cretaceous at Sites 4, 5, 99 and 100 compares well to that of the Maiolica. Radiolarians, mostly preserved as calcite- or silica-filled molds (Plate 11, Figures 3 and
4), are frequent throughout; and calpionellids occur in the lower part of the Maiolica Formation (Plate 11, Figure 8) and-though badly preserved-at Site 100 (Lehmann, this volume). Aptychi that are frequent in the Maiolica have been reported from the TithonianValanginian at Site 5 (M. Ewing et al., 1969).

\section{Sedimentary Structures}

The still soft sediments found in Holes 99A and 100 hardly show any traces of sedimentary structures. Silicified lime turbidites composed of presumable carbonate platform origin (as reported from Site 4; M. Ewing et al., 1969, p. 231) have not been found at Sites 99 and 100 , but their presence in other parts of the section cannot be excluded. In the Maiolica such intercalations are restricted to areas adjacent to a neritic source area (cf. Bernoulli, 1967, 1971; Garrison, 1967).

In the Maiolica facies, the pelagic sediments are sometimes involved in slump folds and mudflows which might reach several meters thickness. At places, pebbly mudstones containing pelagic mud pebbles in a matrix of the same composition and "pelagic turbidites" occur. Whether such structures are present in the corresponding facies of the North Atlantic is difficult to say from the few cores available.

\section{Diagenesis and Formation of Chert}

Replacement origin of the chert bands and nodules is indicated by the depositional texture still preserved in silicified calcarenites and calcilutites. In calcarenites and calcisiltites such replacement phenomena are obvious where the original nature of the former carbonate grains can be easily recognized or where chert nodules cut across sedimentary structures. In homogenous calcilutites and oozes these processes are less obvious, however careful examination often shows that there is no textural variation between calcilutite and chert (for example, Radiolaria wackestonetexture-terminology of Dunham, 1962-in Plate 11, Figure 4). Further arguments for a replacement origin are given by the very irregular, ragged outlines of the chert on a microscopic scale (Plate 11, Figure 3) and the not fully silicified aureole around some of the concretions (Plate 11, Figure 5). Irregular boundaries between coccolith chalk and dark-appearing spongy siliceous aggregates can be seen under the Stereoscan electron microscope (Plate 11, Figure 6).

The observation of hard, fully lithified chert nodules in the unlithified coccolith oozes of Maiolica facies at Site 100 (Plate 11, Figure 5) indicate clearly that the formation of chert nodules took place at an early diagenetic stage prior to lithification of lime mud. In the penecontemporaneous slump-folds that occur in the Maiolica Formation, the lenses and bands of chert 
apparently follow the plastically deformed limestone layers (for example, Parea, 1970, Figure 21). This means either that the cherts were already present at time of the slump movement and were plastically deformed together with the limestones or that selective replacement of folded layers by chert took place at a much later stage (personal communication, A. G. Fischer, 1970; Parea, 1970; Pimm et al., 1971). The second interpretation seems to be favored by cherts that are related to faulting (Parea, 1970) and by the absence of post-Oligocene cherts in pelagic sediments of the Pacific (Pimm et al., 1970); and, in fact, crystallization of the cherts could not be completed before the slump movement took place, as plastic deformation is incompatible with complete crystallization. However, a few observations may suggest that the formation of chert was not one single process, but may have taken place through a number of stages of diagenetic reorganization of silica (Pimm et al., 1971). This might be indicated by the small slump-structure illustrated in Plate 11, Figure 1 where imbricated plates of chert with apparently broken edges are embedded in a fine calcilutite matrix that shows only traces of sediment flow. The immediately overlying bed is not affected by these movements. From this, it seems that the formation of possibly incompletely silicified bands could take place rather early during diagenesis, and that deformation of these occurred at different stages of hardening of the chert, however, before lithification of the lime mud. According to Pimm et al. (1971), no correlations seem to exist between the formation of chert and depth-of-burial as suggested by Parea (1970).

The silica concentrated in the cherts is most probably derived from the dissolution of siliceous organisms: radiolarians in limestones are mostly preserved as calcite-filled molds and, even in silica-filled radiolarians, geopetal infill of fine "sediment" and porefilling silica indicate earlier solution of the skeletons.

Dolomite occurs in tiny rhombs at Sites 99 and 4 (M. Ewing et al., 1969). It has been found in similar limestones in western Greece (Bernoulli and Renz, 1970). Large-scale dolomitization occurs in the Vigla Limestone of western Greece (Institut de Géologie, etc., 1966) and in the M. Gargano area but is probably late diagenetic.

\section{Environment of Deposition}

The Maiolica Formation and its facies equivalents have been deposited in pelagic environments. Influx of terrigenous clays is virtually absent in both formations, and practically all the sediment is derived from planktonic organisms. Compared with the underlying formations, the Maiolica facies contains many less intercalations of slumped beds and this indicates a reduction of the local relief of the sea bottom. In terms of bathymetry the Maiolica and its equivalents have to be placed between the Ammonitico Rosso sediments, which were deposited at somewhat shallower depth, and the Cenomanian radiolarian mudstones (Site 5, M. Ewing et al., 1969), that might have been deposited near compensation depth for calcite.

\section{Marne a Fucoidi versus Upper Tithonian- Hauterivian at Sites 101 and 105}

The Marne a Fucoidi Formation occurs in the Umbrian-Marchean zones and in parts of the Toscanide nappes. In the Southern Alps (Lombardian zone, parts of Trento and Belluno zones) a similar formation (Scaglia Variegata) occurs that is of the same age and has been deposited in parts of the same basin.

The Marne a Fucoidi consist of varicoloured, lilac to pale red, greenish to gray marls, argillaceous marls and marly calcilutites (mostly biomicrites). Intense burrowing of the sediment is a predominant feature (Plate 9, Figures 1 and 4). Some levels are particularly rich in Radiolaria and marked by a higher silica-content that is concentrated in lenses and bands of replacement chert. Dark gray to black, argillaceous, bituminous marls occur as thin intercalations. The lower boundary of the formation is rather sharp, but the upper boundary to the Scaglia Bianca, a formation of pelagic foraminiferal calcilutites (nannomicrites) is gradational. In many places, a 1 to 2 meter-thick member of dark gray to black, bituminous and strongly siliceous argillites, comparable to the Middle Cretaceous black carbonaceous clays in Holes 101A and 105, is present in the lower part of the formation (Plate 9, Figure 2). A similar intercalation, between 1 and 2 meters thick, occurs in the Scaglia at the Cenomanian-Turonian boundary (Plate 9, Figure 3); it extends over the whole Umbrian-Marchean Apennines.

The sediments comparable with the Marne a Fucoidi occur in Hole 101A from 601 to 691 meters (Cores 9 through 14) and in Hole 105 from 403 to 559 meters (Cores 17 through 31). They consist of white to light gray indurated nannoplankton chalks with intercalation of darker organic-rich marls, that make up the larger part of the formation in its uppermost part.

Compared with the corresponding formations from Sites 101 and 105 (Late Tithonian-Hauterivian), the Marne a Fucoidi are distinctly younger; their lower boundary corresponds approximately to the Barremian-Aptian boundary, the upper boundary is gradational and may fall into the Upper Albian or Lower Cenomanian (Luterbacher and Premoli Silva, 1962).

\section{Composition of the Sediment}

The main difference between the Marne a Fucoidi and the underlying Maiolica Formation is the considerable 
higher calcium-carbonate-content in the latter. It is (approximately) 70 to 80 percent in the marly calcilutites and varies between 30 and 60 percent in the marls. These values are somewhat lower than those from the corresponding facies at Sites 101 and 105 (for the Scaglia Variegata see Grunau, 1959 and Bitterli, 1965). Lower calcium carbonate-contents (less than 10 per cent) are characteristic for the siliceous argillites that are rich in organic matter (often between 10 and 20 per cent) and that are comparable to the black clays at Sites 101 and 105. Unfortunately, no detailed investigation on the mineralogical composition of the Marne a Fucoidi has been made up till now; however, from a few preliminary determinations, it appears that clay minerals are mainly illite, with somewhat lesser montmorillonite and traces of kaolinite/chlorite (D. H. Porrenga, personal communication, 1967). Some siltsized quartz is present as well. Comparable associations of clay minerals have been found in North Atlantic Maestrichtian clays from the Cat Gap (Jacobs, 1970).

The fine carbonate fraction in the Marne a Fucoidi and their facies equivalents is mainly composed of coccoliths, nannoconids and their fragments (Plate 10, Figures 3 through 6 for the Marne a Fucoidi; see also Dufour and Noël, 1970). Whereas the sediments from the North Atlantic are only indurated and present a very porous, chalky texture (Plate 10, Figures 2 and 4), the corresponding limestones of the Marne a Fucoidi appear to be lithified by "solution-welding" and rim cementation of nannofossils (Plate 1 in Dufour and Noël, 1970; cf. Fischer et al., 1967).

\section{Fauna}

Radiolaria are frequent throughout the Marne a Fucoidi and their facies equivalents. They mostly appear as calcite-filled molds (Plate 10, Figures 1 and 2 ), in addition the (younger) Marne a Fucoidi contain rich faunas of planktonic foraminifera (Luterbacher and Premoli Silva, 1962). The similarity of the foraminiferal faunas in the siliceous argillites (base of Marne a Fucoidi, Scisti a Pesci in the Scaglia Variegata, Scisti Ittiolitici = Strato Bituminoso in the Scaglia Bianca) and in the black clays at Sites 101 and 105 has been mentioned by Luterbacher (this volume). Additionally pyritized Radiolaria and fish bones are present in these beds. Calpionellids and aptychi that are present in Upper Tithonian-Hauterivian at Sites 101 and 105 are absent in the (younger) Marne a Fucoidi, however, they are frequent in the Oberalm Beds (Upper Tithonian-Berriasian, East-Alpine thrust sheets), that are an intermediate facies between the Maiolica and Marne a Fucoidi (cf. Garrison, 1967).

\section{Sedimentary Structures}

Both, the Marne a Fucoidi and their facies equivalents appear to be well-bedded alternations of darker, argillaceous, laminated sediments and lighter, more calcareous ones, in which the original structure has been largely modified by burrows with darker infills (fucoids, chondrites). Slumping and early diagenetic sediment flow are frequent in the lower part of the formation at Holes 101A and 105, but appear to be restricted to the basal part of the Marne a Fucoidi, near the contact with the underlying Maiolica. In both formations slumping and sediment flow resulted in the formation of limestone clasts and nodules that merge into a darker fluidally or flaser-textured marly matrix; less competent nodular accumulations of limy material are invaded by the darker groundmass. In Hole 105 there are recumbant folds in laminated sediments that are crossed by later burrows (Sample 11-105-24-2, 98 centimeters), but in other cases burrows (fucoids) appear to be deformed by subsequent slumping (Sample 11-105-29-1, 23 to 30 centimeters). In general the deformational structures often resemble the ones in larger slumped units of the Ammonitico Rosso, however, no associated graded beds occur. Graded bedding has only been found in small laminae in the Marne a Fucoidi that are composed of redeposited Radiolaria. The siliceous argillites usually are laminated and show, only exceptionally, traces of some burrowing (Plate 9, Figure 3).

\section{Environment of Deposition}

The Marne a Fucoidi and their counterparts from the western North Atlantic have been deposited in pelagic environments. The main difference with the Maiolica facies is the greater clay content, however, the influx of terrigenous clays is not necessarily related to a major change in bathymetry. The general reduction of slump structures up-section and the disappearance of them in the Marne a Fucoidi and in the black clays indicates, that much of the local relief was eliminated by sedimentation and that by Aptian-Albian times no pronounced local relief existed any longer in both regions.

From the data available, it is very difficult to arrive at any well-reasoned bathymetric figure. However, from the general sedimentary development it seems most likely, that the Upper Tithonian to Hauterivian sequence of the North-American basin has been deposited in a deep bathyal environment, deeper than the one of the Ammonitico Rosso facies but still shallower than the one of the black clays that possibly have been deposited below the compensation depth for calcite. The Marne a Fucoidi have been deposited in the same general environment, but possibly at a somewhat shallower depth: during the Cretaceous the Umbrian-Marchean zones never sank below compensation depth and-as Luterbacher (this volume) pointed out-the siliceous argillites may represent only periods of basin starvation and euxinic conditions without major fluctuation of water depths. In the 
Central Apennines, basin starvation during deposition of the siliceous argillites is indicated by reduced rates of deposition, which are reflected by marked faunal breaks across siliceous intervals.

\section{Monte Sant'Angelo Limestone versus Upper Cretaceous of Tongue of the Ocean}

Sedimentary associations that closely resemble the Upper Cretaceous sediments of the Tongue of the Ocean (Site 98) are widespread in coeval sequences of the central Mediterranean. They consist of red, pink or white Globotruncana-limestones, mostly referred to as Scaglia, that in areas adjacent to carbonate platforms contain numerous intercalations of slump breccias and lime turbidites composed of displaced shallow marine material. (Aubouin, 1959a, 1959b; for other examples see: Ferasin, 1958; Luterbacher and Premoli Silva, 1964 and others). Of these associations, the Monte Sant'Angelo Limestone, a local formation occurring in the eastern Monte Gargano Peninsula, Apulia, has been selected for a number of reasons: in most of the external zones of the peri-Adriatic orogens the Upper Cretaceous sequences have been affected by thrusting and folding and most of the rocks have been fully cemented during late diagenesis. In contrast to this, the rocks of the eastern Gargano Peninsula have not suffered from great overburden by younger formations, and tectonic movements resulted only in faulting, tilting and uplift. Stylolitization that often occurs in the Scaglia is rare and the rocks have preserved much more of their depositional and early diagenetic texture and structure.

The Monte Sant'Angelo Limestone has been described by Mattavelli and Pavan (1965) and by Pavan and Pirini (1965) as a transitional facies between the carbonate platform of Apulia and the deeper marine basin situated east of it (cf. Figure 2). The formation is about 200 meters thick and consists of an alternation of chalky calcilutites with planktonic foraminifera and thick-bedded skeletal limestones that were interpreted by Mattavelli and Pavan, 1965, as "biostromal" deposits and local reef detritus though they did not find any rudists or corals in living position. The sedimentary structures in the ruditic to siltitic intercalations, however, indicate clearly that the shallow water limestone fragments and skeletal debris were deposited by turbidity currents and similar processes (see Plates 12 and 13). This interpretation is much more plausible, as the Monte Sant'Angelo Limestone overlies a pelagic sequence with displaced platform material ("Calcari bioclastici di Mattinata", Pavan and Pirini, 1965), and as both formations grade laterally into purely pelagic limestones (Scaglia). Toward the west, the underlying Mattinata Limestone grades within a few kilometers into coarse reefoidal and fore-reef deposits.
The Monte Sant'Angelo Limestone is of Cenomanian to Lower Senonian age and thus slightly older than the comparable formations in the Tongue of the Ocean (Campanian). It is overlain by Upper SenonianMaestrichtian limestones of similar facies that, however, contain only little pelagic material (Monte Acuto Limestone, Pavan and Pirini, 1965).

The comparable sedimentary association from the Tongue of the Ocean comes from Cores 13 to 15 in Hole 98. It consists of white to slightly yellow nannoplankton chalks with interbedded graded and laminated calcarenites to calcisiltites composed of shallow water material. Occasionally blocks of hard shallow-water limestone occur.

\section{Pelagic Sediments}

The fine, apparently structureless sediment from the Tongue of the Ocean is mainly composed of coccoliths and their fragments (Plate 14, Figure 4 and 6), whether smaller grains of calcite are derived from the decay of coccoliths or formed neomorphically is difficult to say, however it seems that small amounts of neomorphically formed calcite are present as well. The fine, chalky sediment in the Monte Sant'Angelo Limestone is of similar composition, but neomorphically formed calcite occurs in large quantities. In the Scaglia Limestones of the Apennines or the Southern Alps, that have been affected by much overburden, folding and thrusting, the chalky aspect of the rocks has disappeared and the micrites are tightly cemented by "solution-welding" of the coccoliths (cf. Farinacci, 1964; and Fischer et al., 1967 for other examples). In the coarser fractions the pelagic limestones contain planktonic foraminifera (Globotruncana; see M. Caron, in this volume) and an admixture of silt-sized unidentified skeletal material that, in part, might be of shallow water origin (Plate 14, Figures 1 and 2); no aragonitic material, however, has been preserved in these rocks. Replacement cherts do not occur in the Upper Cretaceous of the Tongue of the Ocean or in the Monte Sant'Angelo Limestone; they occur, however, in the Eocene pelagic sequence at Site 98 and in the more basinal Scaglia Limestones.

\section{Redeposited Carbonate Platform Material}

In the Tongue of the Ocean, carbonate particles and skeletal material derived from the adjacent banks contribute largely to the sedimentation in the deeper marine realm. In the Recent and Sub-Recent sediments, the redeposited material occurs as cyclic graded intercalations of carbonate sands and silts, the composition of which does not differ much from the composition of the bank sediments (Ericson et al., 1952; Rusnak and Nesteroff, 1964). The coarse fractions include rare gravel-sized shells, corals and semiconsolidated mud pebbles and sand-sized ooids, 
echinoids, molluscs, Halimeda plates and coral fragments. Silt-sized particles are mainly aragonitic and may therefore be derived from shallow-water sources, whereas, clay sizes are mainly calcite (coccoliths) (Rusnak and Nesteroff, 1964). The associated pelagic sediments are mainly Globigerina oozes and chalks (Ericson et al., 1952).

The sedimentary association found in the Upper Cretaceous at Site 98 matches well with the descriptions of the younger, Late Tertiary to Recent sediments from the Tongue of the Ocean (cf. Ericson et al., 1952; Rusnak and Nesteroff, 1964; Gibson and Schlee, 1967; Andrews et al., 1970 and others), however, no aragonite seems to be preserved in the cores. (X-ray diffraction analysis of Samples 11-98-15-1, 72-75 cm and 11-98-14-1, $69 \mathrm{~cm}$ gave only calcite). The grain sizes vary from fine silt to coarse sand. Gravel-sized fragments, mainly skeletal or pieces of lithified shallow-water limestone, occur as isolated large pebbles or as small pebbles in pebbly mudstones. The grainsizes in the Monte Sant'Angelo Limestone show a wider range, however, all the size classes, components and rock types found in the Upper Cretaceous of the Tongue of the Ocean are represented. The sand-sized components include mainly skeletal fragments, small lithoclasts and pellets; in the silt classes mainly unidentified bioclastic debris are present.

Calcisiltites from the Upper Cretaceous of the Tongue of the Ocean show striking similarities to the finegrained bioclastic intercalations in the Monte Sant'Angelo and Monte Acuto Limestones. Gradedbedding and small-scale current laminations are common features, and, intense burrowing, as observed in modern turbidites in the Tongue of the Ocean, occur in the uppermost part of such beds (Plate 3, Figures 2 and 3). In calcarenites, graded bedding can often be observed in the Monte Sant'Angelo Limestone (Plate 13, Figure 1), but seems to be less pronounced in corresponding rocks from the Tongue of the Ocean. The calcarenites contain mainly rounded to subangular skeletal fragments that are loosely cemented by fine drusy calcite or syntaxial overgrowth. Most of these grains, that sometimes are surrounded by micrite envelopes, are of shallow water origin (rudist fragments, larger benthonic foraminifera, echinoderm remains), but some planktonic foraminifera (Globotruncana) that are included in these sediments suggest that the particles have been transported as individual grains and that cementation took place in the deeper marine environment (Plate 12, Figure 6).

Beside the loosely cemented calcarenites, fragments of coarse, vuggy skeletal limestone (biosparrudites) have been found at Site 98 (Plate 12, Figure 4). They contain rounded skeletal fragments of shallow water origin (rudists, gastropods, calcareous algae), but no planktonic foraminifera. Partly the skeletal grains are strongly recrystallized; most of them are surrounded by micrite envelopes and many of the smaller particles have been completely converted to micrite. Some larger (originally aragonitic) shells have been completely dissolved but their micrite rims are still preserved. This rock type is cemented by a granular interparticle calcite cement that also lines the fossil molds; most probably it has been submitted to leaching and cementation in a subaerial environment and has been introduced as lithified rock fragments into the deeper marine environment of the Tongue of the Ocean. This interpretation is strongly supported by small, cemented rock fragments of this type mixed with displaced neritic and pelagic material in thin intercalations of pebbly mudstone (Plate 13, Figure 5). Skeletal limestones that show no difference of texture or structure occur in the Monte Sant'Angelo Limestone as displaced boulders in graded calcirudites intercalated between the pelagic sediments (Plate 12, Figures 1, 2, 3 and 5).

\section{Environment of Deposition}

The almost identical sedimentary structures and textures in the Upper Cretaceous of the Tongue of the Ocean and the Monte Sant'Angelo Limestone suggest a similar depositional environment for both formations. Both formations consist of nannoplankton chalks with intercalated displaced shallow water material of typical carbonate platform origin. Similar lithologies including pebbly mudstones and graded calcarenites with clasts of shallow-water limestones were encountered during Leg 1 at Sites 4 and 5 in the Middle of Upper Cretaceous (M. Ewing et al., 1969) and in piston cores from the outcrop area of Horizon B (Windisch et al., 1968). Compared with the North Atlantic sediments the Monte Sant'Angelo Limestone apparently contains more proximal turbidites. Unfortunately the stratigraphic frame of the Monte Sant'Angelo Limestone is not very well known. Toward the east the underlying Mattinata Limestone and the Monte Sant'Angelo Limestone grade into a purely pelagic limestone sequence (Scaglia). Toward the west, the Mattinata Limestone (Lower Cretaceous) grades into coarse reefoidal and fore-reef breccias within some 5 to 6 kilometers, and the transition of the Monte Sant'Angelo Limestone into reefoidal deposits seems to take place at a similar order. As no very steep depositional slopes occur it seems that the depositional environment of the Monte Sant'Angelo Limestone was not very deep, perhaps in the order of some hundred, or little more, meters, but certainly not in the order of the present-day Tongue of the Ocean. Such a sedimentary association can be deposited at a great variety of depth; however, as the continental margin on which the Bahamian platforms and the Tongue of the Ocean are situated have been subsiding for about 2500 meters since the Late Cretaceous (Spencer, 1967), water depth in the order of several hundred meters seems to be acceptable for 
the Upper Cretaceous of the Tongue of the Ocean as well, (present depth of the top of Core 13: 3051 meters).

\section{PALEOGEOGRAPHIC AND BATHYMETRIC EVOLUTION, RATES OF SEDIMENTATION}

In Figure 6, palinspastic sections through the southern continental margin of the Tethys are compared with schematic cross-sections through the Atlantic continental margin of the United States (Sheridan et al., 1966; cf. Laubscher, 1969; Dewey and Bird, 1970). Though palinspastic reconstructions in the Mediterranean orogens still contain many uncertainties, some analogies in the paleogeographic evolution of these continental margins may be recognized.

Early phases of rifting at the site of the later southern continental margin of the Tethys is suggested by Middle Triassic basic-to-intermediate volcanics, occurring in graben-like depressions between strongly subsiding carbonate platforms. During the Late Triassic a thick wedge of clastics, evaporites and carbonate sediments accumulated, and by the latest Triassic almost the entire realm to the south of the future Tethyan Ocean was covered by an extensive carbonate shelf, that subsided at a very high rate (approximately $100 \mathrm{~mm} / 10^{3}$ years; cf. d'Argenio, 1970; Garrison and Fischer, 1969). A similar evolution has been reported from the North American continental margin, where tensional rifting, accompanied by volcanic activity occurred in the Late Triassic, and where a comparable wedge of sediments was built up during the Jurassic and the Lower Cretaceous (Rona, 1970). However, rates of subsidence seem to have been considerably smaller. By Aptian-Albian times, the whole of the Blake Plateau and most of the Bahamian region were the site of deposition of shallow water carbonates (Bryant et al., 1969), and only during the Upper Cretaceous were large parts of this carbonate platform submerged.

During the Early Jurassic the carbonate shelf of the southern continental margin was affected by intense block-faulting, most probably connected with spreading in the central parts of the Tethys. As a consequence large parts of the former carbonate shelf were drowned, and only a number of Bahamian-type platforms-separated by deeper troughs-comparable to the Tongue of the Ocean developed. The sediments deposited on the platforms show a facies distribution that is very similar to that of the present situation in the Bahamas (Colacicchi, 1966; Bernoulli, 1967; d'Argenio, 1970); rates of subsidence and sedimentation are in the order of 15 to $40 \mathrm{~mm} / 10^{3}$ years (Accordi, 1965; d'Argenio, 1970), and compare rather well with the values from Andros Island calculated from the data of Spencer (1967) and Goodell and Garman (1969) (cf. Figure 6). In the deeper marine zones adjacent to the carbonate platforms pelagic limestones with intercalated redeposited platform material were deposited; their rate of sedimentation is about half of that in the carbonate platforms (between 7 and $18 \mathrm{~mm} / 10^{3}$ years, approximately $13 \mathrm{~mm} / 10^{3}$ years for the Monte Sant'Angelo Limestones) and is comparable to the values of approximately $8 \mathrm{~mm} / 10^{3}$ years estimated for the Upper Cretaceous of the Tongue of the Ocean.

During the Jurassic and the Cretaceous large parts of the southern continental margin of the Tethys were in a relatively deep-marine realm, comparable in many respects to the Blake Plateau, with local basins and swells that, at least during their early history, were structurally controlled. The basinal sequences indicate a general deepening of the depositional area, comparable to that of the Blake Plateau after the postAlbian (Bryant et al., 1969) to pre-Paleocene (JOIDES, 1965) submergence-and to that of the oceanic realm in the western North Atlantic. During the Middle Liassic (Corniola Formation, Siniais Limestones), rates of sedimentation (pelagic limestones and carbonate turbidites) vary between 15 to $25 \mathrm{~mm} / 10^{3}$ years and more. Rates of sedimentation in the marly Ammonitico Rosso vary between 2.5 and $6.5 \mathrm{~mm} / 10^{3}$ years, whereas, in the North Atlantic facies equivalent values of approximately $3 \mathrm{~mm} / 10^{3}$ years or slightly more are found. Similar values are found in the basinal pelagic lamellibranch limestones $\left(3-8 \mathrm{~mm} / 10^{3}\right.$ years). In the Maiolica and Marne a Fucoidi somewhat higher values are found (up to $10 \mathrm{~mm} / 10^{3}$ years in the Maiolica and up to $15 \mathrm{~mm} / 10^{3}$ years in the Marne a Fucoidi; approximately $8 \mathrm{~mm} / 10^{3}$ years in the Lower Cretaceous at Site 105).

In the stratigraphically reduced sequences, sedimentation rates are much lower (mainly less than $1 \mathrm{~mm} / 10^{3}$ years) and it is quite clear that bulk sedimentation rates in the basinal sequences are mainly dependent on the amount of redeposited material, however, the sedimentation rates in the compared facies are of the same order. This suggests similar production rates of the pelagic sediment and a similar pattern of sediment dispersal that in turn is related to a similar submarine topography and current system.

As subsidence in the southern continental margin of the Tethys was differential and discontinuous (Bernoulli, 1964, 1971), subsidence rates in carbonate platforms and deeper basins might have been quite different. Bathymetric interpretations can not be deducted safely from subsidence rates in the platforms (cf. Garrison and Fischer, 1969); however, a bathyal or even deep bathyal environment can be assumed for the pelagic basinal sequences. During very early phases of sinking, the submarine swells possibly were still situated in the photic zone and sank to bathyal depth only during their later evolution. 
A particular problem is posed by the siliceous mudstones and cherts that occur in parts of the Upper Jurassic of the southern continental margin of the Tethys (for example: basal part of Radiolarite Group in Lombardy; Austro-Alpine thrust sheets-see Garrison and Fischer, 1969; Upper Posidonia Beds in western Greece). According to Garrison and Fischer, these Upper Jurassic radiolarites have been deposited below compensation depth for calcite and, assuming a similar water depth for the latter, this would mean that the continental margin, that is underlain by granitic basement, sank below 4000 meters and was uplifted by the Late Tithonian above compensation depth. On geophysical grounds (granitic basement in probably isostatic equilibrium) such a depression is not very likely, and it could be that compensation depth for calcite was raised during the Middle to Upper Jurassic in connection with intense volcanic activity in the expanding central Tethys.

Similar observations hold true for the Mesozoic sediments of western North Atlantic that were deposited on an oceanic basement, and reflect a general deepening of the sea bottom and a progressive elimination of local topography. Initial water depth may have been in the order of at least several hundred meters and may well have exceeded 1000 meters in places, but compensation depth of calcite was only reached during Early Cretaceous. Though deposited in different paleotectonic settings, the Mesozoic sequences of the southern continental margin of the Tethys and of the North American basin might reflect similar paleotectonic evolution that is connected with the opening of an oceanic area extending from the western Tethys through the central Atlantic to the Caribbean where similar sedimentary associations are observed (for example, Cuba, Bryant et al., 1969 and references therein).

\section{REFERENCES}

Accordi, B., 1965. Il ritmo di sedimentazione, in età assoluta di alcune serie dell'Appennino. Geol. Romana. 4, 221.

Andrews, J. E., Shepard, F. P. and Hurley, R. J., 1970. Great Bahama Canyon. Bull. Geol. Soc. Am. 81, 1061.

Aubouin, J., 1959a. Contribution à l'étude géologique de la Grèce septentrionale: les confins de l'Epire et de la Thessalie. Ann. Géol. Pays Helléniques, 10, 1.

$1959 b$, Granuloclassement vertical ("graded bedding") et figures de courants ("current marks") dans les calcaires purs: les breches de flanc des sillons géosynclinaux. Bull. Soc. Géol. France. (7), 1,578 .
1963. Esquisse paléogéographique et structurale des chaînes alpines de la Méditerranée moyenne. Geol. Rdsch. 53, 480 .

1964. Réflexions sur le faciès "Ammonitico Rosso”. Bull. Soc. Géol. France. (7), 6, 475.

Bernoulli, D., 1964. Zur Geologie des Monte Generoso (Lombardische Alpen). Beitr. Geol. Karte Schweiz (NF). 118, $134 \mathrm{pp}$.

1967. Probleme der Sedimentation im Jura Westgriechenlands und des zentralen Apennin. Verhandl. Natf. Ges. Basel. 78, 35.

1971. Redeposited pelagic sediments in the Jurassic of the Central Mediterranean Area. Ann. Inst. Geol. Publ. Hung. 54(2), 71.

Bernoulli, D. and Jenkyns, H. C., 1970. A Jurassic basin: the Glasenbach Gorge, Salzburg, Austria. Verhandl. Geol. Bundesanstalt Wien. 504.

Bernoulli, D. and Renz, O., 1970. Jurassic carbonate facies and new ammonite faunas from Western Greece. Eclogae Geol. Helv. 63, 573.

Bitterli, P., 1965 Bituminous intercalations in the Cretaceous of the Breggia River, S. Switzerland. Bull. Verhandl. Schweiz. Petrol. Geol. Ing. 31, 179.

Blanchet, R., Cadet, J. P., Charvet, J. and Rampnoux, J. P., 1970. Sur l'existence d'un important domain de flysch tithonique-crétacé inférieure en Yougoslavie: l'unité du flysch bosniaque. Bull. Soc. Géol. France. (7) 11, 871-880.

Bortolotti, V., Dal Piaz, G. V. and Passerini, P., 1969. Ricerche sulle ofioliti delle catene alpine: 5. nuove osservazioni sul massiccio del Vourinos (Grecia). Boll. Soc. Geol. Ital. 88, 35.

Brunn, J. H., 1956. Contribution à l'étude gécologique du Pinde septentrional et d'une partie de la Macédoine occidentale. Ann. Géol. Pays Helléniques. 7,1 .

Brunn, J. H., de Graciansky, Gutnic, M. Juteau, Th., Lefèvre, R., Marcoux, J., Monod, O. and Poisson, A., 1971. Structures majeures et corrélations stratigraphiques dans les Taurides occidentales. Bull. Soc. Géol. France. In press.

Bryant, W. R., Meyerhoff, Brown, N. K., Furrer, M. A., Pyle, T. E., and Antoine, J. W., 1969. Escarpments, reef trends and diapiric structures, Eastern Gulf of Mexico. Bull. Am. Assoc. Petrol. Geologists. 53, 2506.

Colacicchi, R., 1966. Le caratteristiche della facies abruzzese alla luce delle moderne indagini geologiche. Mem. Soc. Geol. Ital. 5 (1), 1. 
Colacicchi, R., Passeri, L. and Pialli, G., 1970. Nuovi dati sul Giurese Umbro-Marchigiano ed ipotesi per un suo inquadramento regionale. Mem. Soc. Geol. Ital. 9,839 .

D'Argenio, B. 1970. Evoluzione geotettonica comparata tra alcune piattaforme carbonatiche dei Mediterranei Europeo ed Americano. Atti Accad. Pontaniana, Nuova Ser. 20, 3.

Decandia, F. A. and Elter, P., 1969. Riflessioni sul problema delle ofioliti nell'Appennino settentrionale (nota preliminare). Atti Soc. Tosc. Sci. Nat., Mem. A. 76, 9 pp.

Dewey, J. F. and Bird, J. M., 1970. Mountain belts and the new global tectonics. J. Geophys. Res. 2625.

Dufour, T. and Noel, D., 1970. Nannofossiles et constitution pétrographique de la "Maiolica", des "Schistes à fucoides" et de la "Scaglia rossa" d'Ombrie. Rev. Micropaléont. 13, 107.

Dunham, R. J., 1962. Classification of carbonate rocks according to depositional texture. Am. Assoc. Petrol. Geologists. Mem. 1, 108.

Emery, K. O., Uchupi, E., Phillips, J. D., Bowin, C. O., Bunce, E. T. and Knott, S. T., 1970. Continental rise off eastern North America. Bull. Am. Assoc. Petrol. Geologists. 54, 44.

Ericson, B. D., Ewing, M. and Heezen, B. C., 1952. Turbidity currents and sediments in North Atlantic. Bull. Am. Assoc. Petrol. Geologists. 36, 489.

Evamy, B. D. and Shearman, D. J., 1969. Early stages in development of overgrowth on echinoderm fragments in limestones. Sedimentology. 12, 317.

Ewing, M., Worzel, J. L., Beall, A. O., Berggren, W. A., Bukry, D., Burk, C. A., Fischer, A. G. and Pessagno, E. A., 1969. Initial Reports of the Deep Sea Drilling Project. Volume I. Washington, (U.S. Government Printing Office).

Farinacci, A., 1964. Microorganismi dei calcari "maiolica" e "scaglia" osservati al microscopio elettronico (Nannoconi e Coccolithophoridi). Boll. Soc. Paleont. Ital. 3, 172.

1965. I foraminiferi di un livello marnoso nei calcari diasprigni del Malm (Monti Martani, Umbria). Geol. Romana. 4, 229.

Ferasin, F., 1958. Il complesso di scogliera cretaceo del Veneto centro-orientale. Mem. Inst. Geol. Mineral., Univ. Padova. 21, 54 pp.

Fischer, A. G., Honjo, S. and Garrison, R. E., 1967. Electron Micrographs of Limestones and their Nannofossils. Princeton (Princeton University Press).

Folk, R. L., 1959. Practical petrographic classification of limestones. Bull. Am. Assoc. Petrol. Geologists. 43,1 .
1962. Spectral subdivision of limestone types. Am. Assoc. Petrol. Geologists, Mem. 1. 62 .

1965. Some aspects of recrystallization in ancient limestones. Soc. Econ. Paleont. Mineral. Spec. Paper 13, 14.

Garrison, R. E., 1967. Pelagic limestones of the Oberalm Beds (Upper Jurassic-Lower Cretaceous), Austrian Alps. Bull. Can. Petrol. Geol. 15, 21.

Garrison, R. E. and Fischer, A. G., 1969. Deep-water limestones and radiolarites of the Alpine Jurassic. Soc. Econ. Paleont. Mineral. Spec. Publ. 14, 20.

Gibson, T. G. and Schlee, J., 1967. Sediments and fossiliferous rocks from the eastern side of the Tongue of the Ocean, Bahamas. Deep-Sea Res. 14, 691.

Goodell, H. G. and Garman, R. K., 1969. Carbonate geochemistry of Superior deep test well, Andros Island, Bahamas. Bull. Am. Assoc. Petrol. Geologists. 53, 513 .

Grunau, H. R., 1959. Mikrofazies und Schichtung ausgewählter, jungmesozoischer, Radiolaritführender Sedimentserien der Zentral-Alpen. Intern. Sediment. Petrograph. Ser. 4, Leiden (Brill).

Hallam, A., 1967. Sedimentology and paleogeographic significance of certain red limestones and associated beds in the Lias of the Alpine region. Scott. J. Geol. 3, 195 .

Hess, H. H., 1962. History of ocean basins. In Petrologic Studies. (A volume to honor A. F. Buddington) Boulder (Geol. Soc. Am.), 599.

Hollmann, R., 1964. Subsolutions-Fragmente. Neues Jahrb. Geol. Paläont., Abhandl. 119, 22.

Institut de géologie et recherches de sous-soul, Athènes et Institut francais du pétrole-mission Grèce, 1966. Etude géologique de l'Epire (Grèce nordoccidentale). Ed. Technip and Inst. Francais Pétrole, Paris, $306 \mathrm{pp}$

Jacobs, M. B., 1970. Clay mineral investigations of Cretaceous and Quaternary deep sea sediments of the North American Basin. J. Sediment Petrol. 40, 864 .

Jenkyns, H. C. and Torrens, H. S., 1969. Palaeogeographic evolution of Jurassic Seamounts in Western Sicily. Ann. Inst. Geol. Publ. Hung. 54(2), 91-104.

JOIDES, 1965. Ocean drilling on the continental margin. Science. 150 (3697), 709.

Laubscher, H. P., 1969. Mountain building. Tectonophysics. 7,551 .

1970. Bewegung und Wärme in der alpinen Orogenese. Schweiz. Mineral. Petrogr. Mitt. 50, 503. 
1971. Das Alpen-Dinariden-Problem und die Palinspastik der südlichen Tethys. Geol. Rdsch. 60, 813.

in press. The large-scale kinematics of the Western Alps and the northern Apennines and its palinspastic implications. Am. J. Sci.

Luterbacher, H. P. and Premoli Silva, I., 1962. Note préliminaire sur une révision du profil de Gubbio, Italie. Riv. Ital. Paleont. 68, 253.

Luterbacher, H. P. and Premoli Silva, I., 1964. Biostratigrafia del limite Cretaceo-Terziario nell'Appennino Centrale. Riv. Ital. Paleont. 70, 67.

Mattavelli, L. and Pavan, G., 1965. Studio petrografico delle facies carbonate del Gargano. Rend. Soc. Mineral. Ital. 21, 207.

Maxwell, A. E., Von Herzen, R. P., Hsü, K. J., Andrews, J. E., Saito, T., Percival, S. F., Milow, E. D. and Boyce, R. E., 1970. Deep sea drilling in the South Atlantic. Science. 168, 1047.

Mercier, J., 1966. Paléogeographie, orogenèse, métamorphisme et magmacisme des zones internes des Hellénides en Macédoine (Grèce): vue d'ensemble. Bull. Soc. Géol. France. (7), 8, 1020.

Noèl, D., 1965. Coccolithes jurassiques. Centre Nat. Rech. Sci. Paris. 209 pp.

Oertli, H. J., 1967. Ostracodes de sédiments bathyaux du Jurassique supérieur de l'Apennin (Italie). Bull. Centre Rech. Pau-SNPA. 1, 7.

Pavan, G. and Pirini, C., 1965. Stratigrafia del foglio 157 "Monte S. Angelo". Boll. Serv. Geol. Italia. 86, 3.

Parea, G. C., 1970. Ricerche sulla genesi delle rocce silicee non detritiche. Mem. Soc. Geol. Ital. 9, 665.

Pilkey, O. H. and Rucker, J. B., 1966. Mineralogy of Tongue of the Ocean sediments. J. Marine Res. 24, 276.

Pimm, A. C., Garrison, R. E. and Boyce, R. E., 1971. Sedimentology synthesis: lithology, chemistry and physical properties of sediments in the northwestern
Pacific Ocean. In Fischer, A. G. et al., 1971, Initial Reports of the Deep Sea Drilling Project. Volume VI. Washington (U. S. Government Printing Office), 1131 .

Rampnoux, J. P., 1970. Sur la géologie du Sandjak: mise en évidence de la nappe du Pester (confins serbo-monténégrins, Yougoslavie). Bull. Soc. Géol. France. (7), 11, 881 .

Rona, P. A., 1970. Comparison of Continental Margins of eastern North America at Cape Hatteras and Northwestern Africa at Cap Blanc. Bull. Am. Assoc. Petrol. Geologists. 54 (1), 129.

Rusnak, G. A., Nesteroff, W. D., 1964. Modern Turbidites: Terrigenous abyssal plain versus bioclastic basin. In: Miller, R. L. (Ed.) - Papers in Marine Geology. Shepard Commemor Vol., New York (Macmillan Comp.).

Sheridan, R. E., Drake, C. L., Nafe, J. E. and Hennion. J., 1966. Seismic refraction study of continental margin east of Florida. Bull. Am. Assoc. Petrol. Geologists. 50 (9), 1972.

Spencer, M., 1967. Bahama deep test. Am. Assoc. Petrol. Geologists. 51, 263.

Sturani, C., 1964. La successione delle faune ad ammoniti nelle formazioni mediogiurassiche delle Prealpi venete occidentali. Mem. Ist. Geol. Mineral. Univ. Padova. 24, 1.

Trümpy, R., 1960. Paleotectonic evolution of the Central and Western Alps. Bull. Geol. Soc. Am. 71, 843.

Trümpy, R., in press. The timing of orogenic events in the Central Alps.

Voigt, E., 1962. Frühdiagenetische Deformation der turonen Plänerkalke bei Halle/Westf. als Folge einer Grossgleitung unter besonderer Berücksichtigung des Phacoid-Problems. Mitt. Geol. Staatsinst., Hamburg. 31, 146.

Windisch, C. C., Leyden, R. J., Worzel, J. L., Saito T. and Ewing, J., 1968. Investigation of Horizon Beta. Science. 162, 1473. 
PLATE 1

Pelagic Limestones of the Mediterranean Jurassic

Figure 1 Slump folded complexes intercalated between normally deposited pelagic calcilutites (radiolarian biomicrites) and marls.

The slumped rocks are plastically deformed, locally retextured (Plate 5, Figures 2, 4, 7, 8) light gray, yellow or red calcilutites with bands of replacement chert and marly interbeds. At places blocks of undeformed stratified pelagic limestones indicate submarine lithification prior to slump movement. Some of the slump complexes are overlain by carbonate turbidites that contain exclusively intraformational (pelagic) limestone clasts and pelagic fossils.

Corniola Formation, Middle Liassic (Domerian), Umbrian Zone, Central Apennines.

Road from Apecchio to Acqualagna at the locality Gorgo a Cerbara, about $3 \mathrm{~km}$ east of Piobbico, Province of Pesaro, Italy.

Figure 2 Detail of Figure 1. Well-bedded, light gray, and red pelagic calcilutites (biomicrites) rich in calcitized radiolarians and interbedded lilac marls, overlain by large slump-complex composed of light gray to yellow, chaotically deformed pelagic limestones and marls. A small steep Alpine fault cuts obliquely through the stratigraphic contact between the normal pelagic sediments and the slump mass.

Corniola Formation, Middle Liassic (Domerian), Umbrian Zone, Central Apennines.

Road from Apecchio to Acqualagna to the locality Gorgo a Cerbara, about $3 \mathrm{~km}$ east of Piobbico, Province of Pesaro, Italy. 
PLATE 1
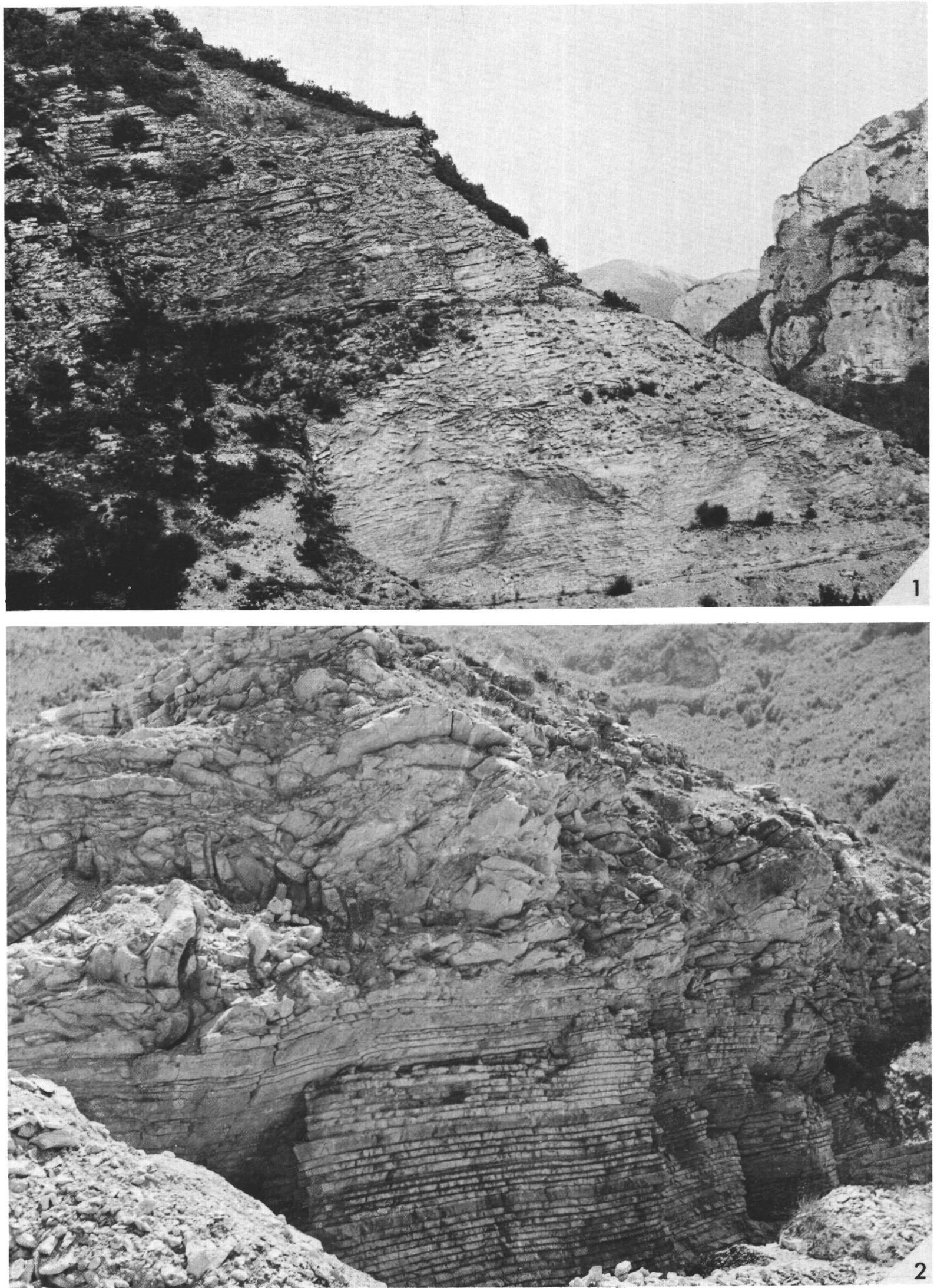
PLATE 2

Ammonitico Rosso Facies of the Central Apennines

Figure 1 Slump-folded complexes in the Ammonitico Rosso and the lower-most Pelagic Lamellibranch Limestones.

The slump-folded complexes consist of contorted and lenticular beds of dark red to pink nodular marls and marly calcilutites (biomicrites containing pelagic lamellibranchs and calcitized radiolaria). At places they pass laterally into pebbly mudstones which, in a retextured marly matrix, contain sparse nodules of pelagic limestone (cf. Figure 3). The non-tectonic origin of these structures is clearly indicated by the stratigraphic contacts at their top: they are overlain by graded calcirudites and calcarenites that pass into marly lime mudstones. The arrow indicates the stratigraphic position of the graded bed illustrated in Figure 2.

Ammonitico Rosso and lowermost pelagic Lamellibranch Limestones. Upper Liassic - Lower Dogger, Umbrian Zone, Central Apennines.

Bosso Valley, along road from Cagli to Pianello, about $4 \mathrm{~km}$ southwest Secchiano, province of Pesaro, Italy.

Figure 2

Graded and laminated calcirudite to calcarenite, overlying a 2.3 meter-thick slumped complex (see Figure 1). The calcarenite grades upwards into calcisiltite and apparently structureless red marly lime mudstone. The mudstone is obviously linked to the graded bed and represents the finest fraction of the turbidite: in contrast to the overlying limestone of normal deposition, the homogenous mudstone has not been burrowed. Sample DB 2989 (Plate 3, Figures 2 and 4 ) comes from the base of this graded bed.

Ammonitico Rosso, Toarcian-Aalenian, Umbrian Zone, Central Appenines.

Bosso Valley, along road from Cagli to Pianello, about $4 \mathrm{~km}$ southwest of Secchiano, province of Pesaro, Italy.

Figure 3 Pebbly mudstone containing sparse nodules of pelagic limestone in marly matrix.

Ammonitico Rosso, Toarcian-Aalenian, Umbrian Zone, Central Apennines.

DB 2207, Valdorbia, along road from Scheggia to Sassoferrato, about $2 \mathrm{~km}$ east of Scheggia, province of Perugia, Italy. 


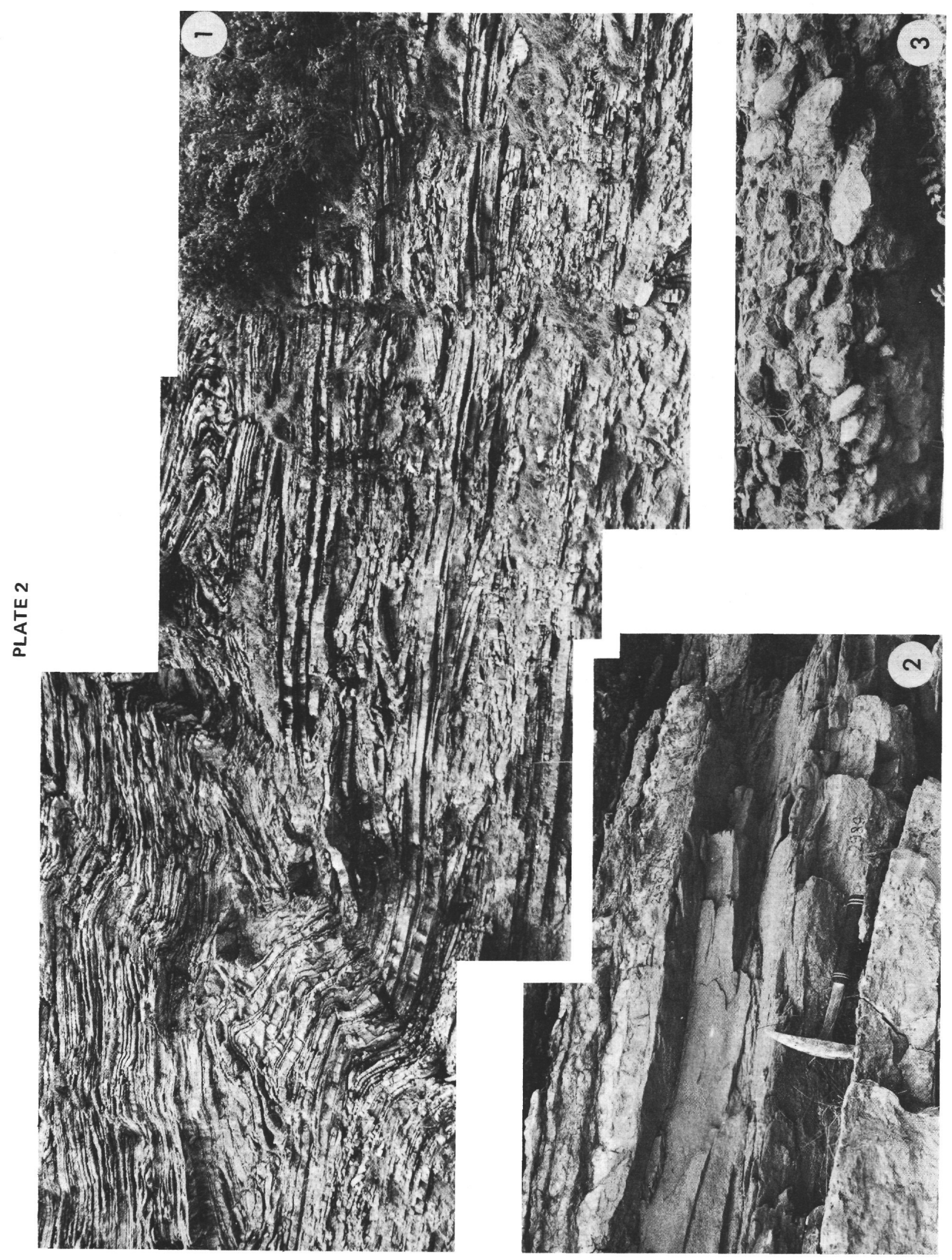


PLATE 3

Ammonitico Rosso versus Upper Jurassic of Western North Atlantic

Figure 1 At base: red and white spotted, nodular marls and marly calcilutites of typical Ammonitico Rosso facies. They are overlain by a slump bed, which in a light gray and red colored, fluidally-textured matrix contains sparse nodules and lenses of white and light gray pelagic limestone. This pebbly mudstone is in turn overlain by a graded calcarenite passing upwards into homogenous marly mudstone (cf. Plate 2, Figure 2).

Ammonitico Rosso, Toarcian-Aalenian, Ionian Zone, Western Greece.

North of the village of Kouklessi, Louros Valley, Epirus, Greece.

Figure 2

Detail of Plate 2, Figure 2. Graded and laminated calcirudite to calcarenite. The basal part of this turbidite consists of closely-packed, irregularlyshaped intraclasts of pelagic calcilutites (radiolarianpelagic lamellibranch biomicrite); in the upper part there are small intraclasts and pelagic lamellibranchs. The shape of the pelagic mud pebbles has been largely modified by postdepositional pressure-solution. As the equivalent rock types from the western North Atlantic (Plate 3, Figure 3; Plate 4, Figure 1) do not show sutured contacts between mud pebbles, the pressure-solution phenomena are most likely of late diagenetic origin.

Ammonitico Rosso, Toarcian-Aalenian, Umbrian Zone, Central Apennines.

Bosso Valley, along road from Cagli to Pianello, about $4 \mathrm{~km}$ southwest of Secchiano, province of Pesaro, Italy.

DB 2989; polished surface, natural size.

Figure 3 Dark red mud-pebble conglomerate, passing upwards into graded and laminated, red and greenish-gray calcarenite and calcisiltite. At the base, a small layer of fine calcisiltite is present that is overlain rather abruptly by the conglomerate. The conglomerate contains mainly flattened pelagic mud-pebbles, but aptychi, echinoderm fragments, inoceram prisms, foraminifera (Lenticulina) and some small fragments of green volcanic material are also present. The mud-pebble conglomerate grades continuously into the overlaying graded calcarenite that is composed of small interclasts and pelagic lamellibranchs (Figures 5, and 6). The finest fraction of the turbiditic layer (not on photograph, cf. Plate 4, Figure 1) is represented by a homogenous marly mud-stone without traces of burrowing. 


\section{PLATE 3 - Continued}

Upper Jurassic: Oxfordian-Kimmeridgian.

DSDP 11-105-38-2, 94-106 cm; sliced core, natural size.

Figure $4 \quad$ Basal part of turbidite illustrated in Figure 2. The components consist exclusively of pelagic calcilutite (radiolarian-pelagic lamellibranch biomicrite) and of pelagic lamellibranchs. No terrigenous clastics or components derived from a carbonate platform are present.

Ammonitico Rosso, Toarcian-Aalenian, Umbrian Zone, Central Apennines.

Bosso Valley, along road from Cagli to Pianello, about $4 \mathrm{~km}$ southwest of Secchiano, province of Pesaro, Italy.

DB 2989; negative-print from thin-section, $\times 3.5$.

Figure 5 Coarse calcarenitic fraction of turbidite illustrated in Figure 3. Components are chiefly pelagic lime intraclasts, pelagic lamellibranch shells and some echinoderm fragments. Some silt-sized quartz.

Upper Jurassic: Oxfordian-Kimmeridgian.

DSDP 11-105-38-2, $100 \mathrm{~cm}$; negative-print from thin-section, $\times 3.5$

Figure 6 Fine fraction of turbidite illustrated in Figure 3, composed of pelagic lamellibranchs and badly preserved Radiolaria. The pelagic lamellibranch shells show early diagenetic replacement overgrowth of syntaxial calcite similar to the one found in analogous rocks from the Mediterranean Jurrasic.

Upper Jurassic: Oxfordian-Kimmeridgian.

DSDP 11-105-38-2, $98 \mathrm{~cm}$; negative-print from thinsection, $\times 3.5$ 


\section{PLATE 3}
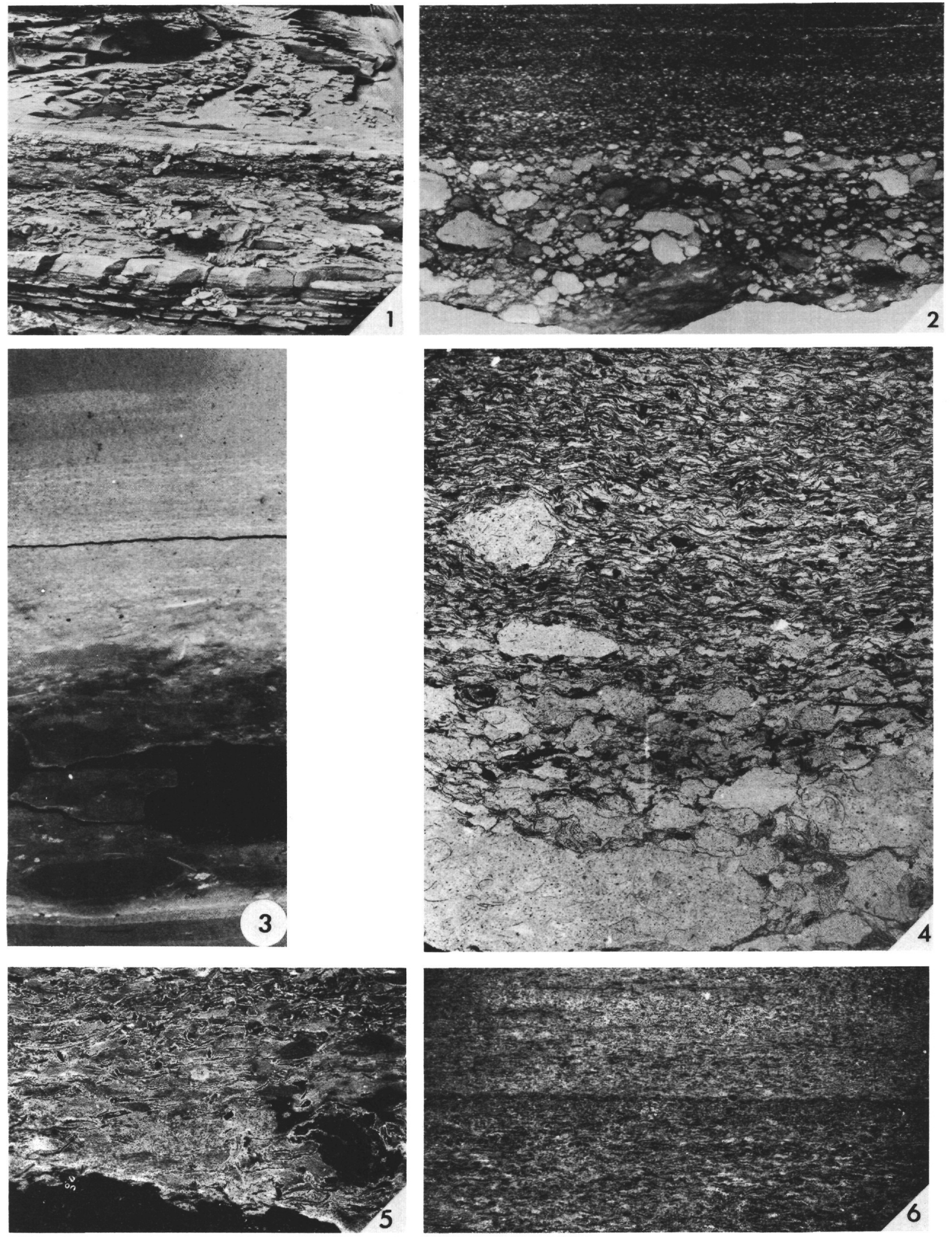


\section{PLATE 4}

Ammonitico Rosso versus Upper Jurassic of Western North Atlantic

Figure 1 Complete cycle of a "pelagic" turbidite. The cycle starts with a conglomerate that, in a muddy matrix, contains flattened pebbles of pelagic marly calcilutite. As in Plate 3, Figure 3, and in similar rocks from the Tethyan Jurassic (Plate 3, Figure 1) they pass gradually into the overlaying graded and laminated interval. The finest fraction of the turbidite is represented by a structureless marly mudstone without burrows (cf. Plate 2, Figure 2, Plate 3, Figure 1 ), that in turn is overlain by a small bed of graded skeletal fine calcarenite to calcisiltite.

Upper Jurassic: Oxfordian-Kimmeridgian.

DSDP 11-105-37-5, 91-112 cm; sliced core natural size.

Figure 2 Carbonate turbidite, composed of pelagic limestone clasts and pelagic organisms (pelagic lamellibranchs and calcitized Radiolaria, additionally some crinoid ossicles).

Ammonitico Rosso, Toarcian-Aalenian, Umbrian Zone, Central Apennines.

Valdorbia, along road from Scheggia to Sassoferrato, $2 \mathrm{~km}$ east of Scheggia, province of Perugia, Italy.

DB 1825; polished surface, natural size.

Figures 3, 4 Graded and laminated calcirudite to calcisiltite, composed of intraclasts, pelagic lamellibranchs and some calcitized Radiolaria. As in Figure 2, the color boundaries between the red (original) and the white color runs obliquely to the sedimentary structures and is thus due to postdepositional decoloration.

Upper Jurassic: Oxfordian-Kimmeridgian.

DSDP 11-105-36-6, 138-148 cm; 3: sliced core natural size; 4 : negative-print from thin-section, $\times 3.5$.

Figure $5 \quad$ Graded skeletal calcarenite to calcisiltite intercalated between pelagic lamellibranch calcilutites (biomicrites).

Pelagic Lamellibranch Limestones, Middle Jurassic, Ionian Zone, Western Greece.

North of the village of Kouklessi, Louros Valley, Epirus, Greece. DB 1500; negative-print from thinsection, $\times 3.5$. 
PLATE 4
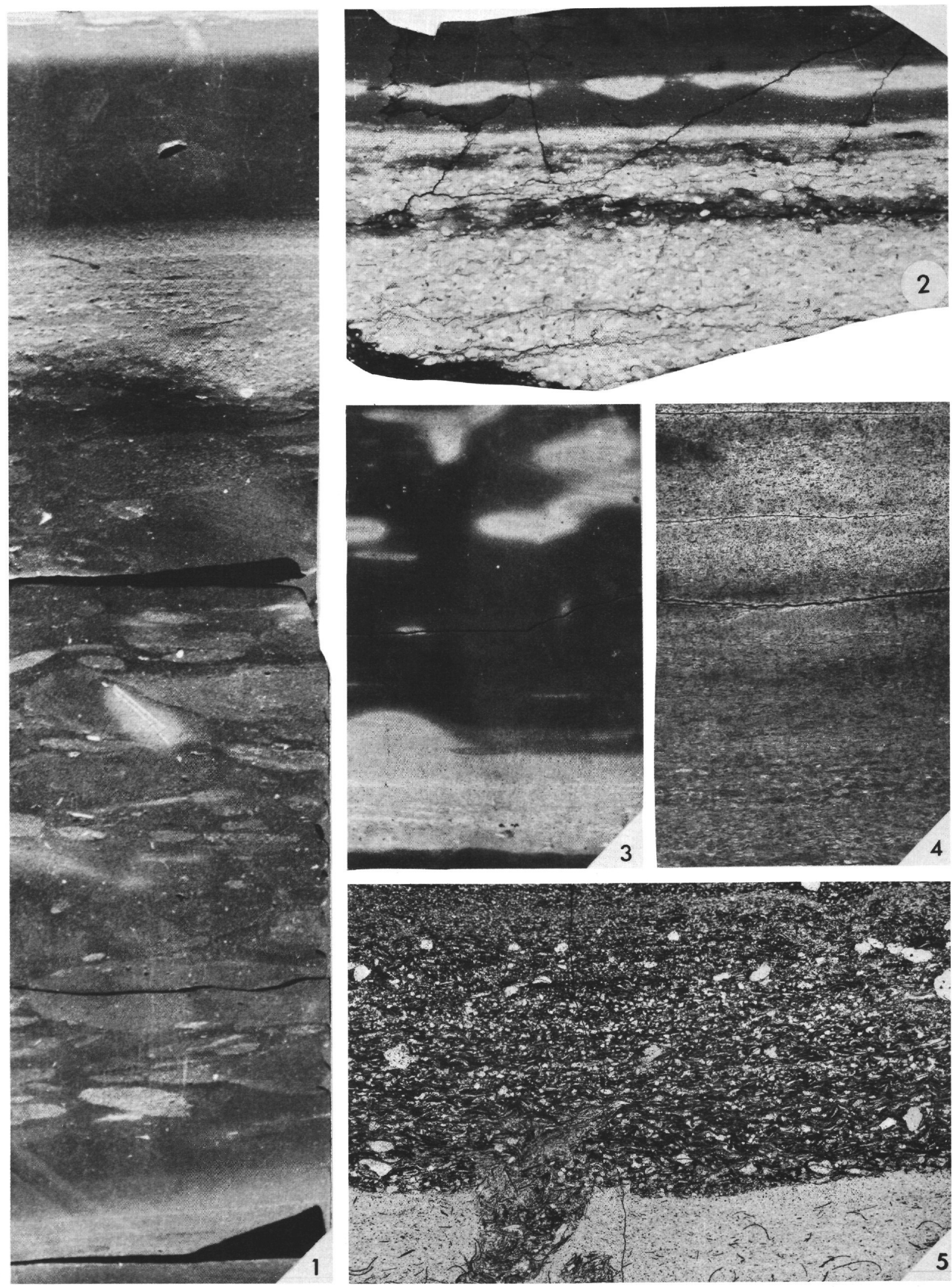


\section{PLATE 5}

Ammonitico Rosso versus Upper Jurassic of Western North Atlantic

Figure 1

Dark red, fluidally textured marls with clasts of white pelagic limestone. The marls show early diagenetic flow folds due to penecontemporaneous slumping. The white limestone is a lithified nannoplankton ooze (cf. Plate 8, Figure 5) rich in pelagic lamellibranch shells and with dolomitized burrows.

Upper Jurassic: Kimmeridgian-Middle Tithonian.

DSDP 11-105-36-2, 96-99 cm; sliced core, $\times 0.5$.

Figure 2 Plastically deformed dark red marly pelagic calcilutites (biomicrites) with irregular shaped clasts of white calcilutite. The laminar texture is not a sedimentary lamination, but results from sediment flow during early diagenesis. The specimen comes from one of the slump complexes illustrated in Plate 1 , Figure 1.

Corniola Formation, Middle Liassic (Domerian), Umbrian Zone, Central Apennines.

Road from Apecchio to Acqualagna at the locality Gorgo a Cerbara, about $3 \mathrm{~km}$ east of Piobbico, province of Pesaro, Italy.

DB 1910; polished surface, natural size.

Figure 3 Fluidally textured red marly calcilutites with nodules of red calcilutite. The laminar texture is the result of penecontemporaneous sediment flow as shown by intensely deformed limestone clasts with tails that merge into the secondary lamination. Note the absence of burrowing in this type of structure.

Upper Jurassic: Kimmeridgian-Middle Tithonian.

DSDP 11-105-34-3, top; sliced core, natural size.

Figure $4 \quad$ Fluidally textured calcilutite with pelagic limestone clasts of the same composition. Some of the clasts show very vague outlines or locally merge without a sharp boundary into the groundmass: this indicates that many of the pebbles had not been lithified prior to slump movement. Sutured contacts that locally occur are due to postdepositional solution.

Corniola Formation, Middle Liassic (Domerian), Umbrian Zone, Central Apennines.

Road from Apecchio to Acqualagna near the locality Gorgo a Cerbara, about $3 \mathrm{~km}$ east of Piobbico, province of Pesaro, Italy.

DB 1941; polished surface, natural size. 


\section{PLATE 5 - Continued}

Figures 5,6 Flow structure in white to light brown marly calcilutite (biomicrite, with aptychi and calcitized radiolaria, cf. Plate 8, Figure 1).

Upper Jurassic: Upper Tithonian.

DSDP 11-105-33-1, 57.5-60.5 cm; 5: sliced core, natural size; 6 : negative print from thin-section, $\times 6$.

Figures 7,8 Flow structure and plastically deformed limestone clasts in slump-folded pelagic calcilutites (fine biomicrites) and marls. (See Plate 1, Figure 1).

Corniola Formation, Middle Liassic (Domerian), Umbrian Zone, Central Apennines.

Road from Apecchio to Acqualagna at the locality Gorgo a Cerbara, about $3 \mathrm{~km}$ east of Piobbico, province of Pesaro, Italy.

DB 1911; 7: polished surface, natural size; 8: negative-print from thin-section, $X 6$. 
PLATE 5
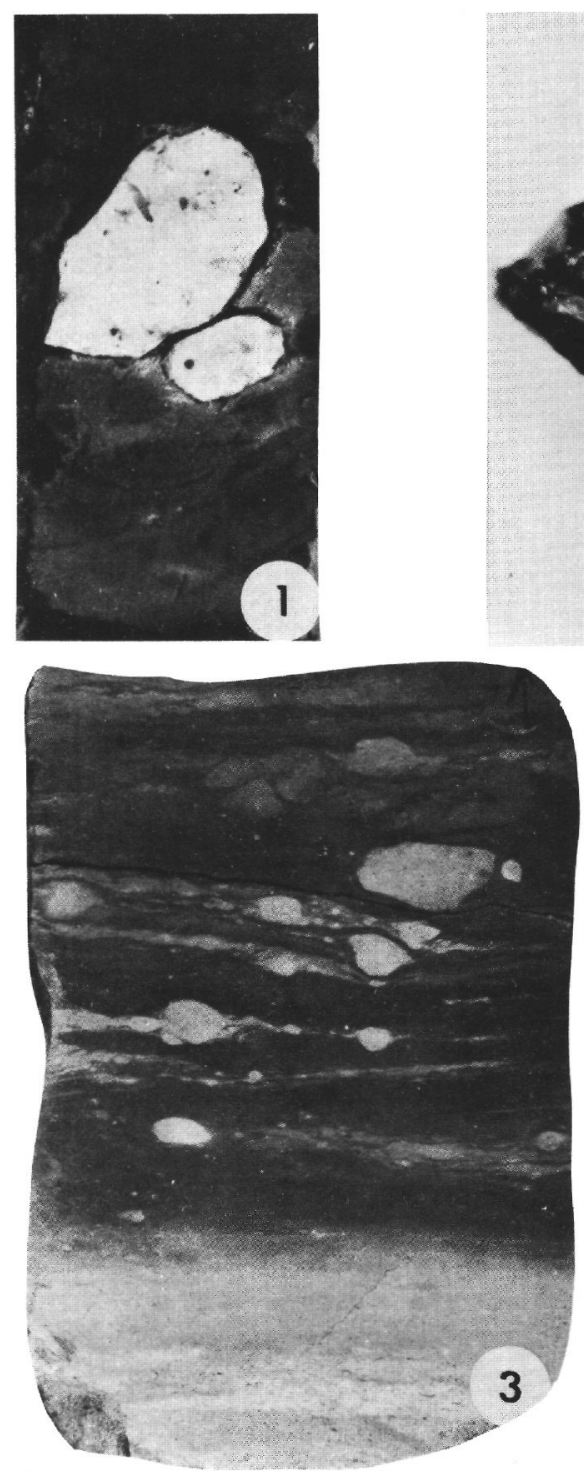

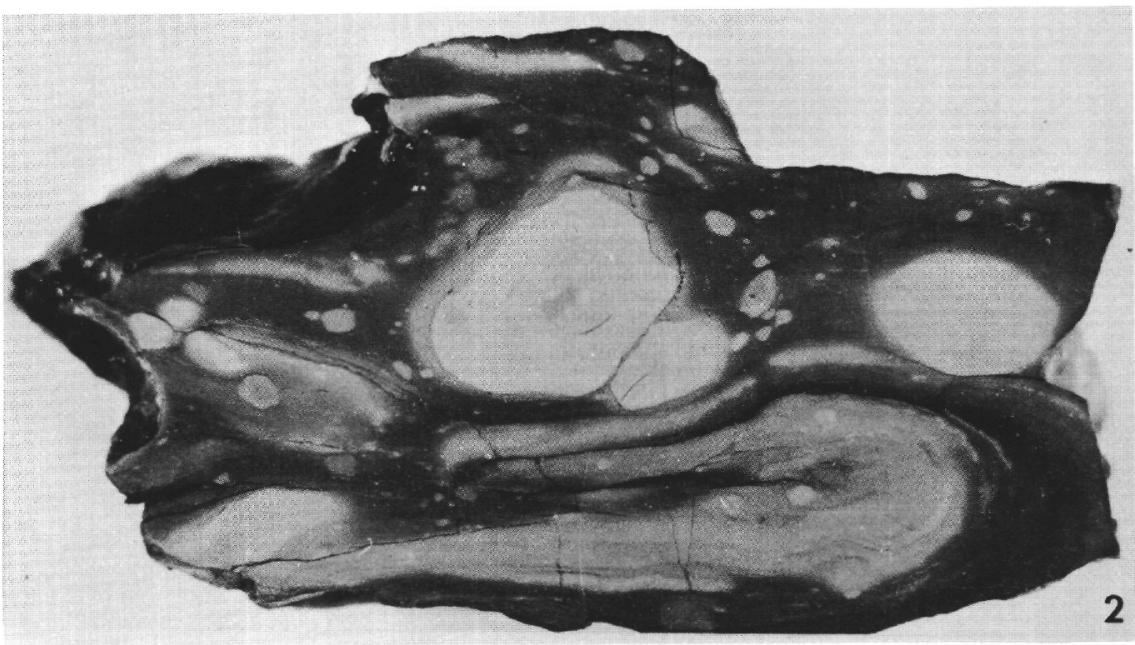

2
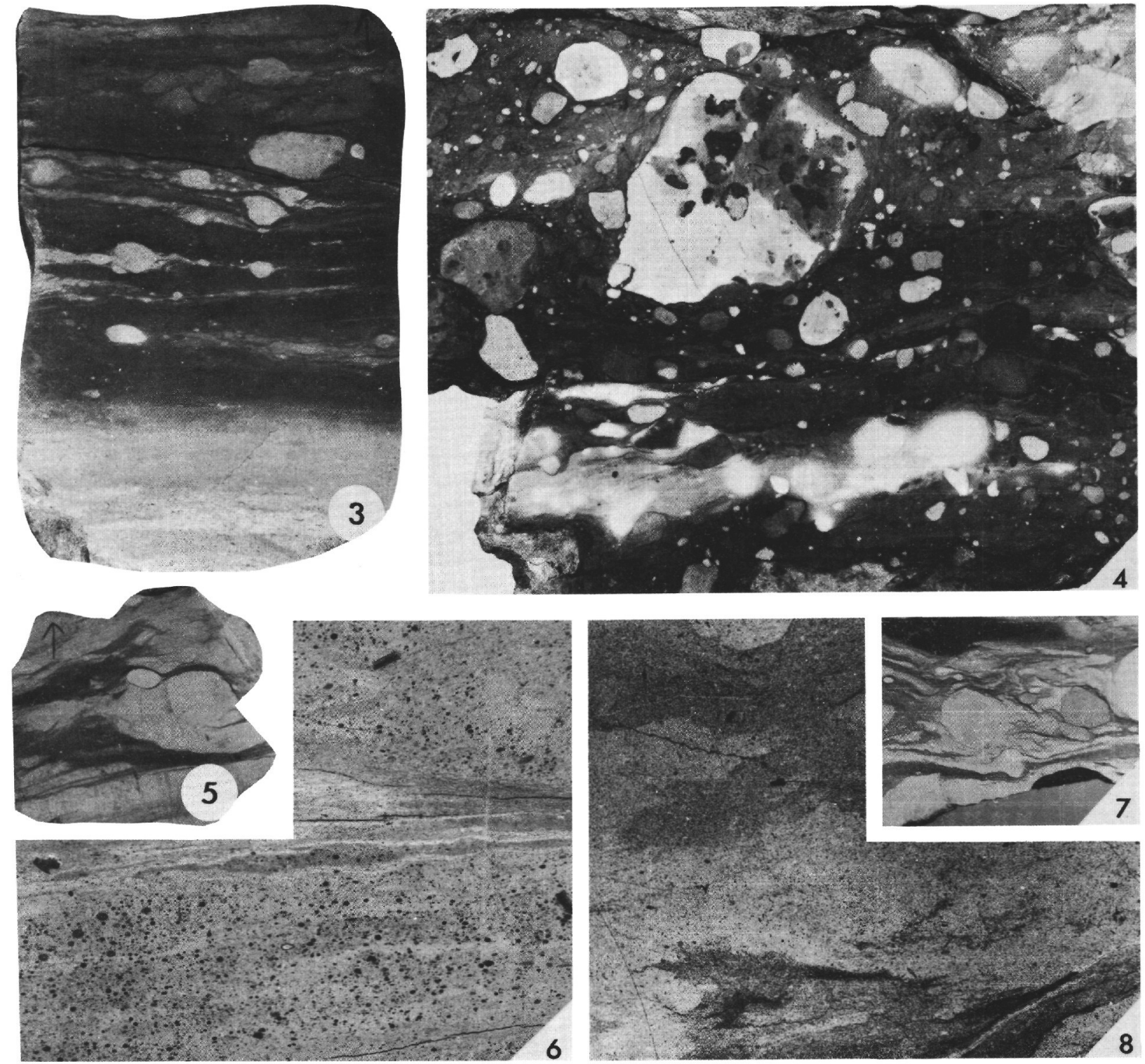



\section{PLATE 6}

Ammonitico Rosso versus Upper Jurassic of Western North Atlantic

Figure 1 Graded calcarenite to calcilutite, entirely composed of pelagic mud-pebbles (radiolarian/pelagic lamellibranch biomicrites) and pelagic fossils. Some porosity filled with sparry calcite cement (dark).

Ammonitico Rosso, Toarcian-Aalenian, Ionian Zone, Western Greece. North of the village of Kouklessi, Louros Valley, Epirus, Greece.

DB 1496; negative-print from thin-section, $\times 6$.

Figure 2 Calcarenite containing redeposited pelagic material. The pelagic mud pebbles show very irregular outlines and locally merge into the matrix that is of the same composition. Skeletal grains (a.o. pelagic crinoids (Saccocoma), aptychi) are surrounded by replacement overgrowth of syntaxial calcite. Well-preserved Stomiosphaera occur frequently, sometimes even in the sparry calcite of the syntaxial overgrowth.

Upper Tithonian-Valanginian.

DSDP 11-105-32-5, 96-100 cm; negative-print from thin-section, $\times 6$.

Figure 3 Pebbly mudstone, containing clast of pelagic calcilutite (biomicrite with calcitized Radiolaria) in a fluidally textured matrix of pelagic calcilutite. Different orientation of geopetal fabrics in the limestone nodules indicates that these are derived clasts. The pebbly mudstone is overlain by a "pelagic" lime turbidite.

Ammonitico Rosso, Toarcian-Aalenian, Ionian Zone, Western Greece.

North of the village of Kouklessi, Louros Valley, Epirus, Greece.

DB 1489; negative-print from thin-section, $\times 6$.

Figure 4 Intraformational conglomerate showing nodules of Radiolaria-rich calcilutite set in a fine-grained siliceous limestone matrix. The Radiolaria are only badly preserved spherules, filled with fine aggregates of crystalline silica; sometimes, however, a geopetal infill of fine carbonate material is present that shows that the silica-aggregates are mold-filling cements. As in Figure 3, the geopetal fabrics show different orientation in the different components proving the sedimentary nature of the conglomerate.

Upper Jurassic: Kimmeridgian-Middle Tithonian.

DSDP 11-100-3-1, bottom; negative print from thinsection, $\times 6$. 


\section{PLATE 6 - Continued}

Figure 5 Slump conglomerate containing pebbles of skeletal calcilutite (biomicrite), rich in aptychi, pelagic crinoids (Saccocoma), Stomiosphaera and calcitized Radiolaria, set in a clay- and hematite-rich matrix of the same composition.

At its base, the large pebble shows indications of postdepositional pressure solution (sutured contacts, cut-off skeletal grains); postdepositional solution of carbonate material in the matrix is suggested by thin flaser-textured clay seams enriched in hematitic pigments. The slump conglomerate is overlain by a graded "pelagic" calcarenite.

Uppermost part of Scisti ad Aptici Formation: Rosso ad Aptici, Kimmeridgian-Middle Tithonian. Umbrian Zone, Central Apennines.

Road from Fiastra to Bolognola, about $2.5 \mathrm{~km}$ north-west of Bolognola, province of Macerata, Italy.

DB 2400; negative-print from thin-section, $\times 6$.

Figure 6 Calcirudite containing pebbles and small clasts of skeletal calcarenite and calcilutite in a somewhat more argillaceous matrix. The large clast at the left contains small pebbles of pelagic calcilutites, skeletal elements as aptychi, pelagic crinoids (Saccocoma, surrounded by calcite overgrowth of replacement origin), set in somewhat recrystallized calcite matrix. The pebbles contain some rare, calcite-replaced ammonite embryos, whereas the matrix contains no remnants of aragonitic fossils. The irregular shape of the clasts indicate that the clasts had not been fully lithified when they were transported. The groundmass shows a fluidal texture which might be accentuated by postdepositional solution phenomena as observed in Figure 5. Both pebbles and groundmass are rich in Stomiosphaera. Radiolaria that frequently occur in the groundmass appear as fossil molds.

Upper Jurassic: Kimmeridgian-Middle Tithonian.

DSDP 11-105-34-2, 129-135 cm; negative-print from thin-section, $\times 6$. 
Plate 6
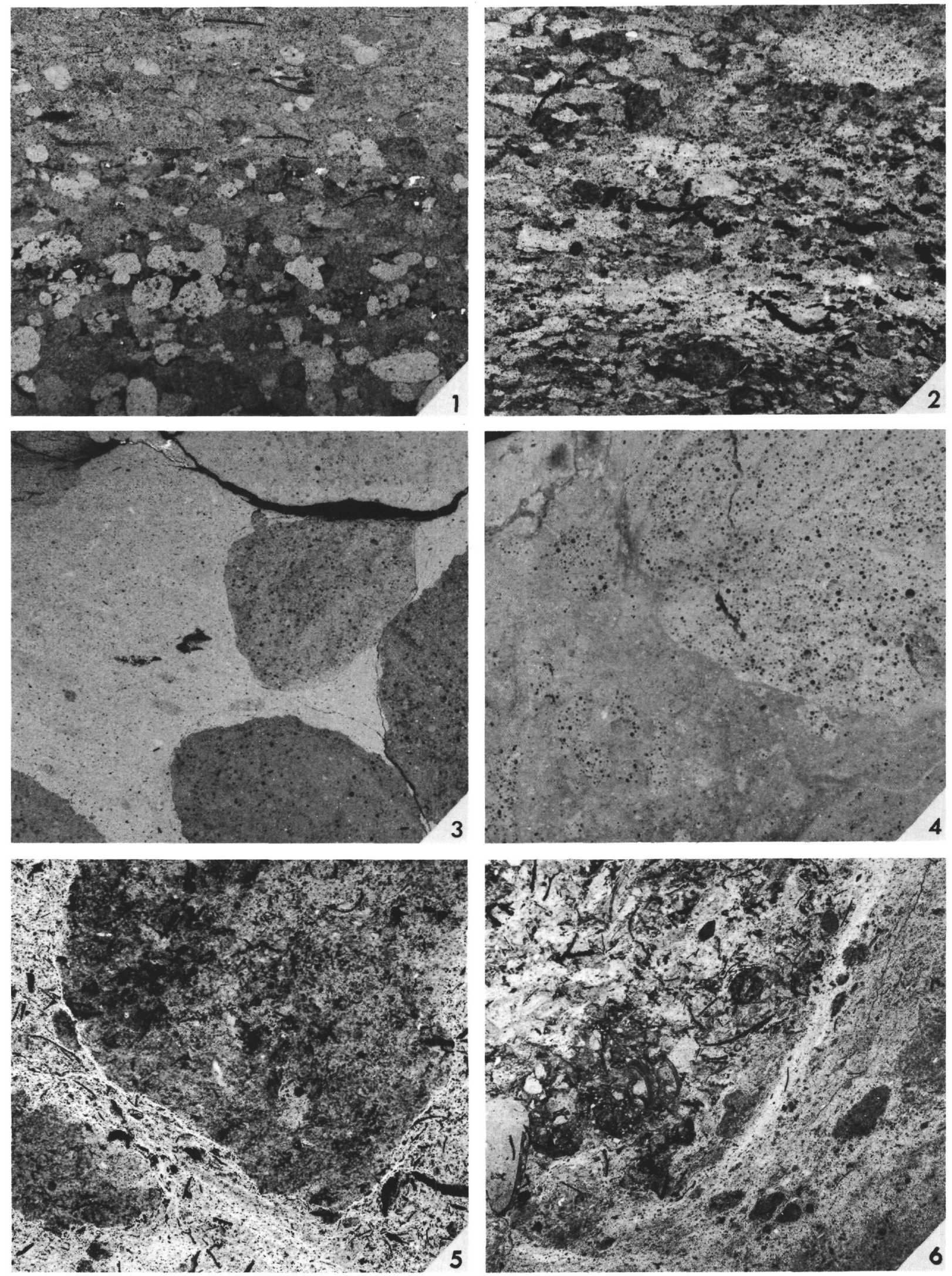

PLATE 7

Rosso ad Aptici versus Upper Jurassic of Western North Atlantic

Figure 1 Skeletal limestone, mainly composed of pelagic crinoids (Saccocoma), aptychi and Radiolaria. The crinoid fragments which make up the largest part of the skeletal material show large syntaxial replacement overgrowths by calcite.

The original hematite-rich matrix, in which the Radiolaria appear as silica-filled spherules, has been largely replaced by finely crystalline silica.

Rosso ad Aptici. Radiolarite Group s. 1., Kimmeridgian-Middle Tithonian. Lombardian Zone, Southern Alps.

Alpe di Mendrisio. M. Generoso, Canton Ticino, Switzerland. Thin-section, $\mathrm{X} 6$.

Figure 2 Graded skeletal limestone containing pelagic crinoid fragments (Saccocoma), pelagic intraclasts and in the finer fraction numerous Stomiosphaera. Sheltered cavities below larger crinoid fragments have been partly filled with large syntaxial calcite overgrowths, whereas large parts of the original sediment have been replaced by spherulitic aggregates of chalcedony, that also fill part of the pore space in sheltered cavities and between particles. In the uppermost part of the layer that has not been silicified Radiolaria appear as calcite-filled spherules.

Upper Jurassic: Kimmeridgian-Middle Tithonian.

DSDP 11-105-34-3, 31-35 cm; thin section, $\times 6$.

Figure 3 Calcirudide (intramicrudite) that in a matrix of pelagic calcilutite contains irregularly shaped mud pebbles of similar composition (Radiolaria biomicrite). Locally the pebbles show sutured contacts toward the clay- and hematite-enriched matrix. Part of the pebbles and fossils show incipient chertification (dark areas); in cases, however, the silicification may overlap the boundary of the pebbles indicating that chertification was not terminated after deposition of the rock.

Rosso ad Aptici. Radiolarite Group s. 1., Kimmeridgian-Middle Tithonian. Lombardian Zone, Southern Alps.

Alpe di Mendrisio, M. Generoso, Canton Ticino, Southern Switzerland. Negative-print from thinsection, $\times 6$. 


\section{PLATE 7 - Continued}

Figure 4 Red calcilutite (upper part, white; radiolarian biomicrite) largely replaced by silica. In the chert the original depositional texture is still visible. In the zone adjacent to the calcilutite the chert is finer grained and contains many impurities, whereas, in the black appearing areas it consists of aggregates of finely crystalline silica.

Kimmeridgian - Middle Tithonian.

DSDP 11-100-2-2, $140 \mathrm{~cm}$; negative-print from thinsection, $\times 6$.

Figure 5 "Radiolarian chert": Silica-filled Radiolaria in a somewhat calcitic, cryptocristalline siliceous matrix stained by hematitic pigments.

Radiolarite group s. 1., Kimmeridgian-Middle Tithonian, Lombardian Zone, Southern Alps.

Alpe di Mendrisio, Monte Generoso, Canton Ticino, Southern Switzerland.

Thin-section, $\times 30$.

Figure 6 "Radiolarian chert". Silica-filled Radiolaria in a slightly calcareous siliceous matrix stained by hematitic pigments.

Kimmeridgian-Middle Tithonian.

DSDP 11-100-3-1, top; thin-section, $\times 30$. 
Plate 7
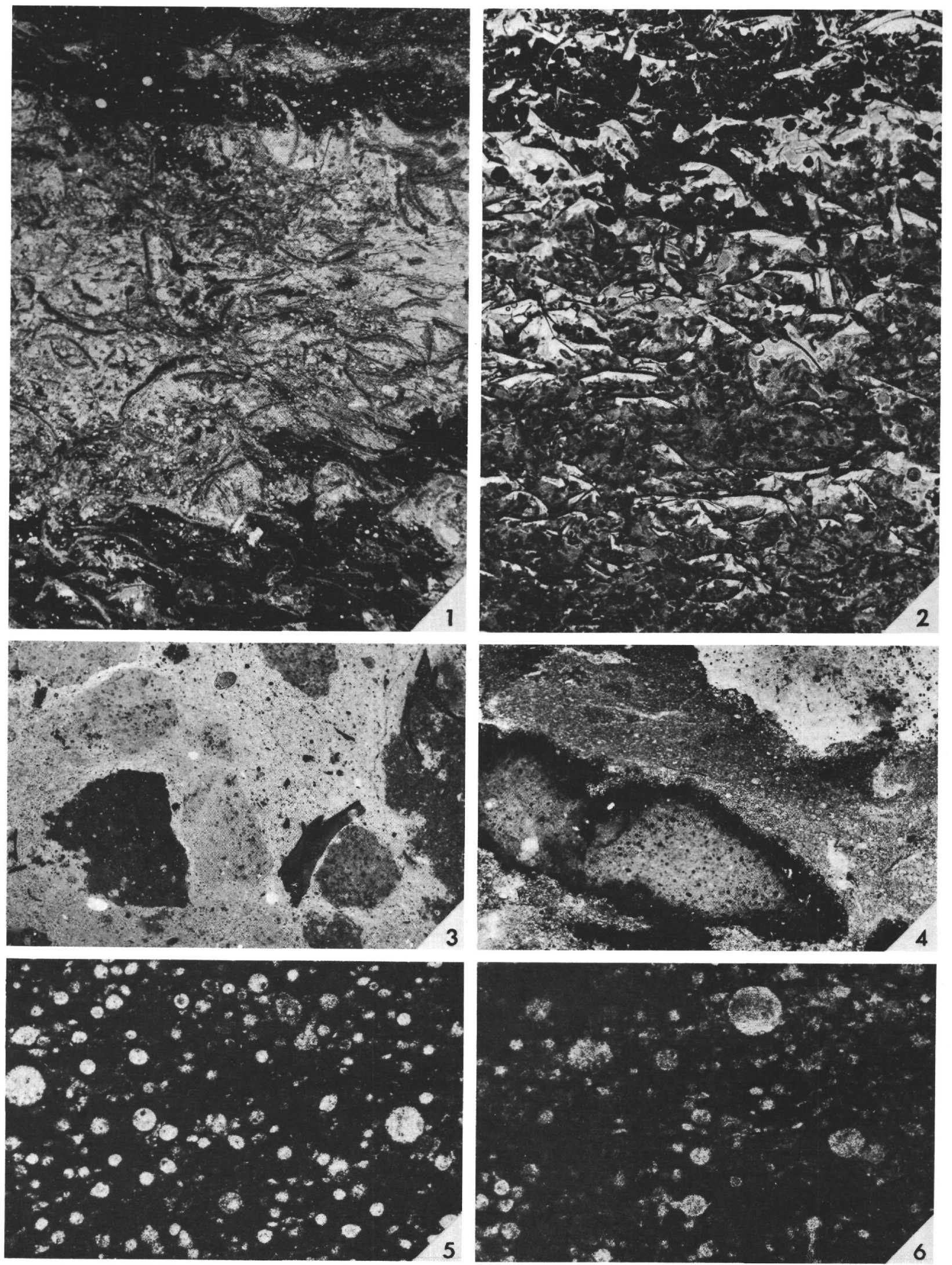

PLATE 8

Ammonitico Rosso versus Upper Jurassic of Western North Atlantic

Figure 1

Figure 3

Figure 4

Figure 5
Fine sediment of nannoplankton chalk mainly composed of coccoliths and unidentified calcite grains.

Upper Tithonian-Berriasian.

DSDP 11-105-33-1, $40 \mathrm{~cm}$; Stereoscan electron micrograph of fresh broken surface gold- and carboncoated, $\times 2000$.

Fine sediment of nannoplankton chalk composed of large coccoliths and fine-grained ? calcite, that has possibly originated from the disintegration of tests of planktonic nannoorganisms (cf. Figure 6). Larger calcite crystals have been formed neomorphically.

Kimmeridgian to Middle Tithonian.

DSDP 11-100-3-cc, Base; Stereoscan electron microscope of fresh broken surface, gold- and carboncoated, $\times 2000$.

Fine sediment of greenish-gray nannoplankton chalk containing clay minerals, coccoliths and neomorphically formed calcite.

Upper Jurassic: Oxfordian-Kimmeridgian.

DSDP 11-100-7-1, 111-120 cm; Stereoscan electron micrograph of fresh broken surface, gold- and carbon-coated, $\times 2000$.

Groundmass of condensed pelagic limestone of submarine swell-facies of the Tethyan Upper Jurassic. Most of the fine sediment is composed of coccoliths and their fragments that are cemented by "solutionwelding". Clay minerals are virtually absent.

Pelagic cephalopod limestones, Upper Jurassic, Ionian Zone, Western Greece.

East of the village of Klissoura, Louros valley, Epirus, Greece. DB 1483; Stereoscan electron micrograph of fresh broken surface, gold-coated, $\times 2000$.

Groundmass of white pelagic limestone pebble associated with slump-folded pelagic marls and marly calcilutites (cf. Plate 5, Figure 1). The fine fraction consists of coccoliths, clay minerals and neomorphically formed calcite.

Upper Jurassic. Kimmeridgian-Middle Tithonian.

DSDP 11-105-36-2, 86-90, $5 \mathrm{~cm}$; Stereoscan electron micrograph of fresh broken surface, gold- and carboncoated, $\times 2000$. 


\section{PLATE 8 - Continued}

Figure 6

Groundmass of marly calcilutite of Pelagic Lamellibranch Limestone. The small calcite crystals are elements of more or less disintegrated tests of a planktonic organism that has been described by Noël (1965) as Schizosphaerella Deflandre and Dangeard, 1938. Small coccoliths and neomorphically formed calcite.

Pelagic Lamellibranch Limestones, Middle Jurassic, Umbrian Zone, Central Apennines.

Valdorbia, road from Scheggia to Sassoferrato, about $2 \mathrm{~km}$ east of Scheggia, province of Perugia, Italy.

DB 1841; Stereoscan electron micrograph of fresh broken surface, gold-coated, $\times 2000$.

Figure $7 \quad$ Groundmass of red marly calcilutite containing coccoliths, neomorphically formed calcite and clay minerals.

Upper Jurassic: Oxfordian-Kimmeridgian.

DSDP 11-105-34-4, $120 \mathrm{~cm}$; Stereoscan electron micrograph of fresh broken surface, gold- and carbon-coated, $\times 2000$.

Figure $8 \quad$ Groundmass of red calcilutite (Radiolaria biomicrite) with badly preserved coccoliths in a neomorphically formed calcite fabric.

Rosso ad Aptici, Upper Jurassic: KimmeridgianMiddle Tithonian, Lombardian Zone, Southern Alps.

Alpe di Mendrisio. Monte Generoso, Canton Ticino, Switzerland.

Stereoscan electron micrograph of fresh broken surface, gold- and carbon-coated, $\times 5000$.

Figure 9 Fine sediment of laminated gray marly calcilutite mainly composed of coccoliths and clay minerals.

Upper Jurassic: Oxfordian-Kimmeridgian.

DSDP 11-105-37-2, 85-87 cm; Stereoscan electron micrograph of fresh broken surface, gold- and carbon-coated, $\times 5000$. 
PLATE 8
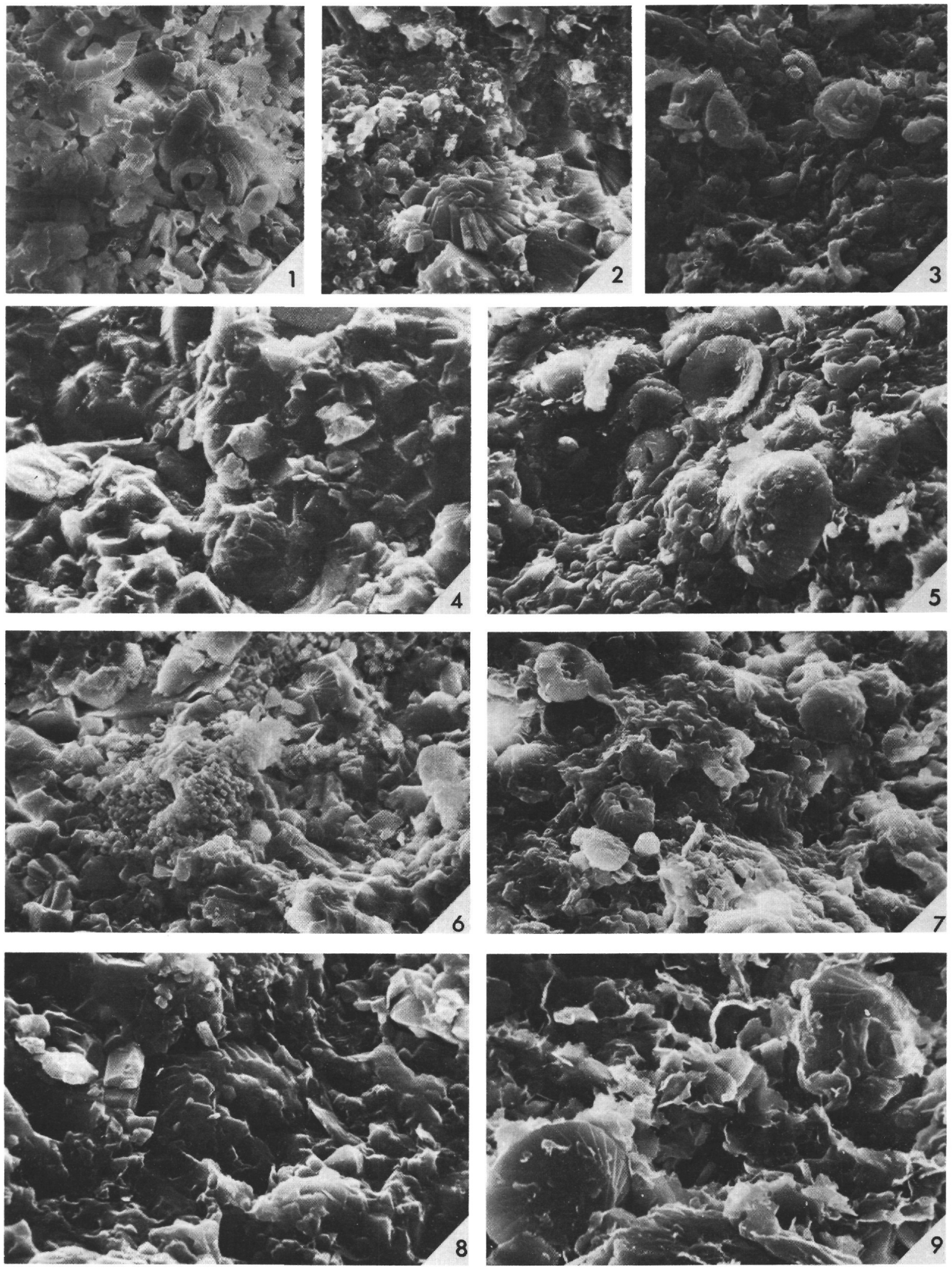

PLATE 9

Marne a Fucoidi versus Upper Tithonian-Hauterivian of Sites 101 and 105

Figure 1

Light gray, marly calcilutite (foraminiferal biomicrite) showing intense burrowing (fucoids). View perpendicular to bedding.

Marne a Fucoidi, Aptian-Albian, Marchean Zone, Central Apennines.

Metauro River, about $1.5 \mathrm{~km}$ west of Fossombrone, province of Pesaro, Italy.

Figure 2

Intercalation of black, siliceous and bituminous argillites in Marne a Fucoidi Formation. The Marne a Fucoidi consists of a well-bedded alternation of light gray to pink, strongly burrowed calcilutites (biomicrites, planktonic foraminifera, calcitized Radiolaria) and variegated marls.

Marne a Fucoidi, Aptian-Albian, Umbrian Zone, Central Apennines.

Locality I Molini, Nera Valley, road from Visso to Terni, province of Perugia, Italy.

Figure 3 Light gray, slightly greenish and black, bituminous siliceous argillite with traces of burrowing, rich in Radiolaria and fish bones.

Scisti Ittiolitici, Cenomanian-Turonian boundary, Umbrian Zone, Central Apennines.

Southern flanc of Candigliano Valley, south of Sassorotto, between Apecchio and Piobbico, province of Pesaro, Italy,

DB 653; polished surface, natural size.

Figure 4 Light gray, slightly greenish, strongly burrowed calcilutite (radiolarian biomicrite) (Plate 10, Figures $1,3,5)$.

Marne a Fucoidi, Aptian-Albian, Marchean Zone, Central Apennines.

Metauro River, about $1.5 \mathrm{~km}$ west of Fossombrone, province of Pesaro, Italy.

DB 730; polished surface, natural size.

Figure 5 Alternation of white nannoplankton chalk and dark gray more argillaceous chalk.

Upper Tithonian-Valanginian.

DSDP 11-105-29-3, 100-106 cm; sliced core, natural size. 


\section{PLATE 9 - Continued}

Figure 6

Medium gray, finely-laminated calcilutite (nannoplankton chalk) with calcitized Radiolaria (see Plate 10 , Figures 2,6).

Upper Tithonian-Valanginian.

DSDP 11-105-25-2, 122-125 cm; sliced core, natural size.

Figure $7 \quad$ Green-gray marly calcilutite (nannoplankton chalk) showing numerous burrows with infill of dark gray material.

Valanginian-Hauterivian.

DSDP 11-105-18-4, 51-61 cm; sliced core, natural size.

Figure 8 Light gray marly calcilutite (nannoplankton chalk), intensely burrowed.

Upper Tithonian-Valanginian.

DSDP 11-105-29-3, 33-39 cm; sliced core, natural size. 
PLATE 9
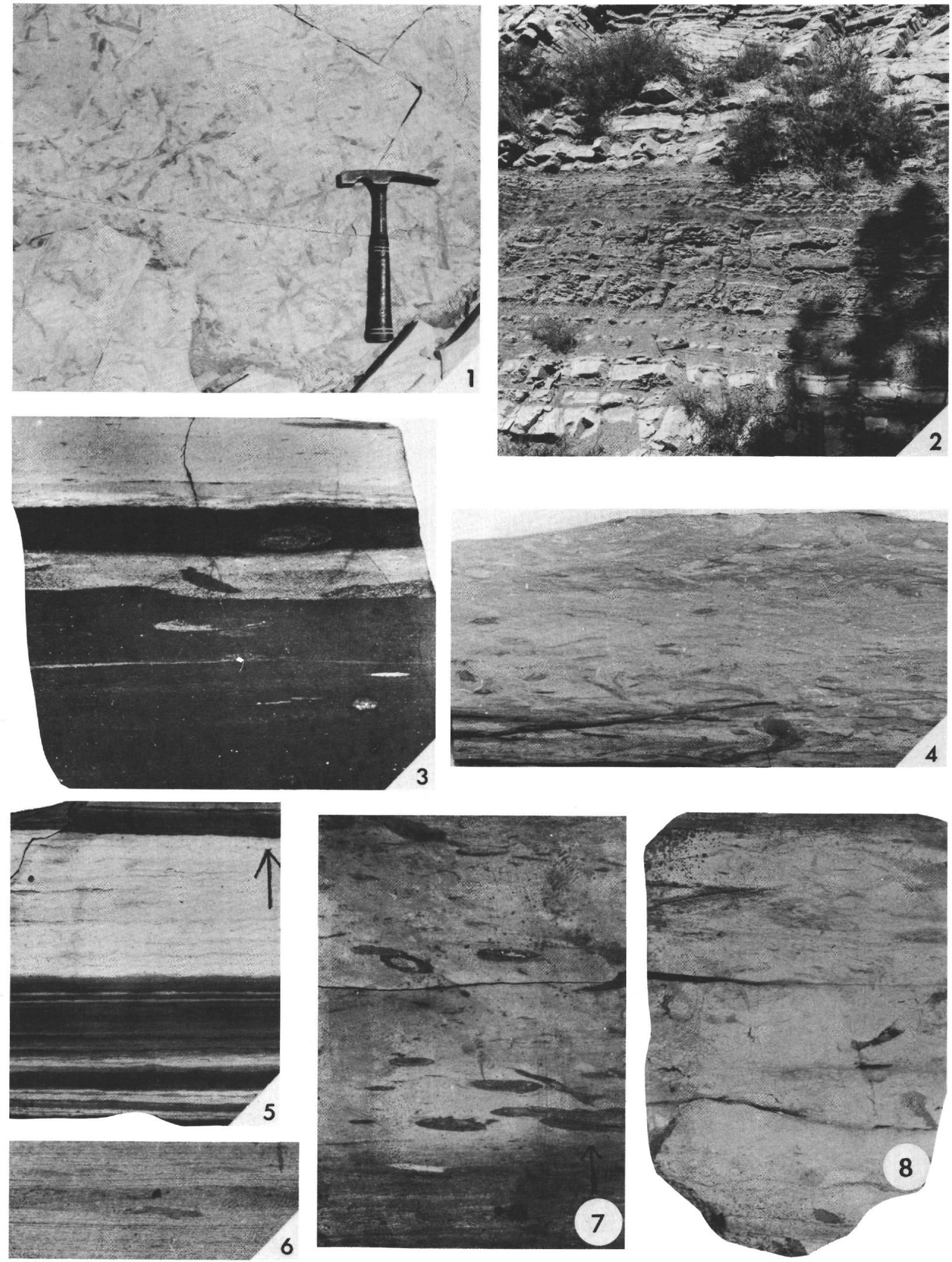



\section{PLATE 10}

Marne a Fucoidi versus Upper Tithonian-Hauterivian

Figure 1 Marly calcilutite (biomicrite) containing calcitized Radiolaria. Marne a Fucoidi, Aptian-Albian, Marchean Zone, Central Apennines.

Metauro River, about $1.5 \mathrm{~km}$ west of Fossombrone, province of Pesaro, Italy.

DB 730; thin-section, $\times 20$.

Figure 2 Laminated calcilutite (nannoplankton chalk) with calcitized Radiolaria.

Upper Tithonian-Valanginian.

DSDP 11-105-25-2, 122-125 cm; thin-section, $\times 20$.

Figures 3,5 Groundmass of marly calcilutite, mainly composed of coccoliths and their fragments, clay minerals and neomorphically formed calcite.

Marne a Fucoidi, Aptian-Albian, Marchean Zone, Central Apennines.

Metauro River, about $1.5 \mathrm{~km}$ west of Fossombrone, province of Pesaro, Italy.

DB 730; Stereoscan electron micrographs of fresh broken surfaces, gold- and carbon-coated; $3: \times 2000$; 5: $\times 5000$.

Figures 4, 6 Nannoplankton chalk, the fine sediment is nearly entirely composed of coccoliths and their fragments. Stereoscan electron micrographs of fresh broken surface, gold- and carbon-coated; 4: DSDP 11-105-18-1, 28-45 cm; Valanginian-Hauterivian, $\times 2000$; 6: DSDP 11-105-25-2, 122-125 cm; Upper Tithonian-Valanginian, $\times 5000$.

Maiolica versus Upper Tithonian-Lower Cretaceous at Sites 99 and 100

Figure 7 Groundmass of lithified calcilutite of Maiolica composed of coccoliths and neomorphically formed calcite.

Base of Maiolica Formation, Upper Tithonian, Umbrian Zone, Central Apennines.

Along road from Fiastra to Bolognola, about $2.5 \mathrm{~km}$ north-west of Bolognola, province of Macerata, Italy.

DB 2404; Stereoscan electron micrograph of fresh broken surface, gold- and carbon-coated, $\times 5000$. 


\section{PLATE 10 - Continued}

Figure 8

Fine sediment of unlithified nannoplankton ooze of Maiolica facies. From the lithified equivalent from the Apennines, this sediment differs mainly by the absence of neomorphically formed calcite.

Upper Tithonian-Valanginian.

DSDP 11-100-1-3, 4-5 cm; Stereoscan electron micrograph of fresh broken surface, gold- and carboncoated, $\times 5000$. 
Plate 10
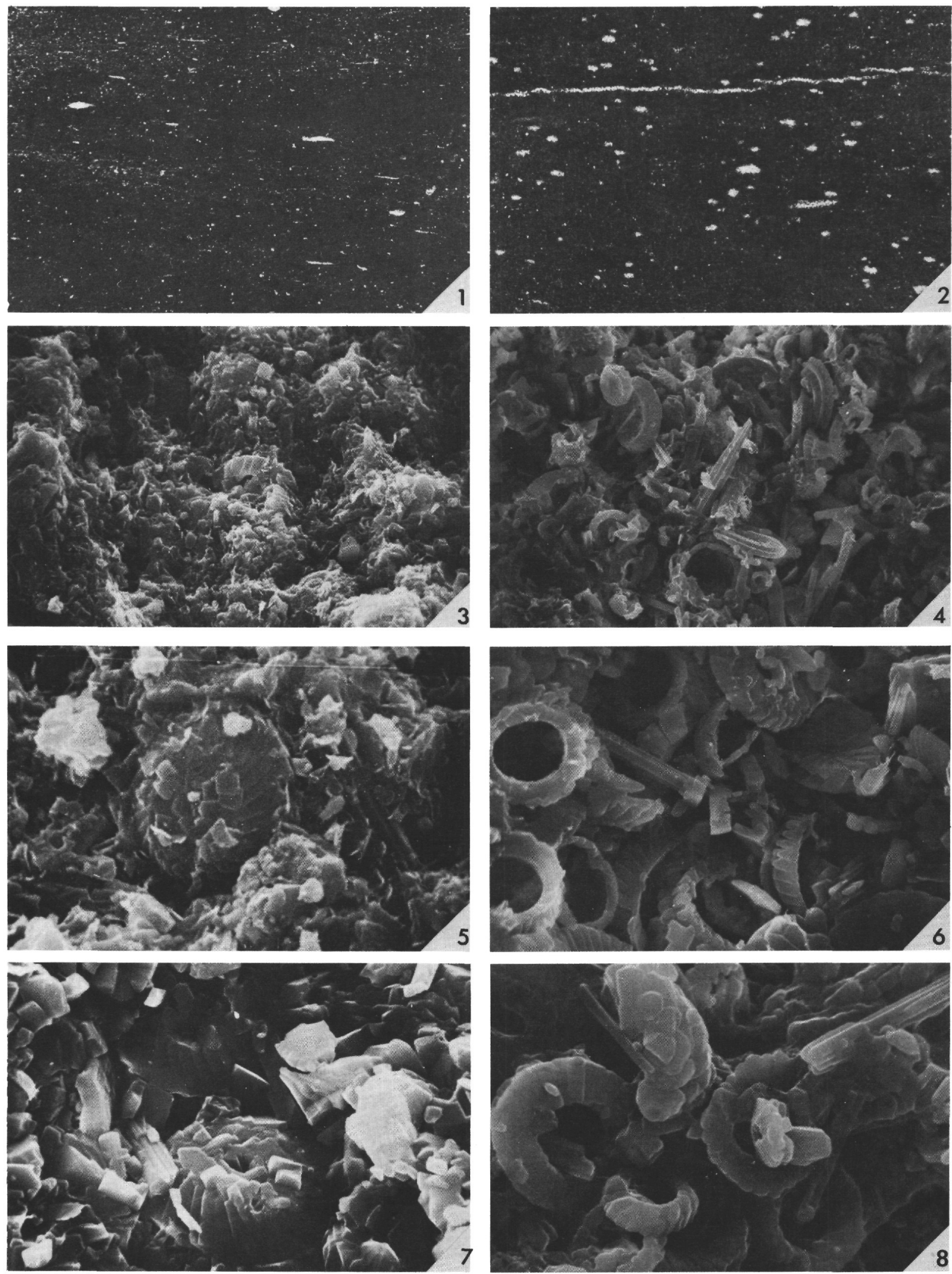

PLATE 11

Maiolica versus Upper Tithonian-Lower

Cretaceous at Sites 99 and 100

Figure 1 White, well-bedded calcilutite (Globotruncana biomicrite) with imbricated plates of red chert. The chert plates are either fragments of a continuous band (cf. Figure 2) of early diagenetic replacement origin that was broken up and displaced by submarine slumping, or originated from selective silicification. As the chert plates show sharp, broken edges and the enclosing calcilutite show only traces of plastic deformation, an early stage of possibly incomplete silicification before slumping and lithification of the lime mud seems probable.

Vigla Limestone (Maiolica). Coniacian, Ionian Zone, Western Greece.

South of the village of Poros, Lefkas Island, Greece.

Figure 2 Typical aspect of Maiolica facies: white, well-bedded calcilutites (biomicrites with calcitized radiolaria) with lenses and bands of black replacement chert.

Vigla Limestone (Maiolica), Upper Tithonian-Lower Cretaceous, Ionian Zone, Western Greece.

Between the villages of Khanopoulon and Gribovon, north of Arta, Greece.

Figure 3 Irregular, ragged contact between replacement chert (dark) and pelagic calcilutite (white) containing Radiolaria preserved as mold-filling aggregates of finely crystalline silica.

Upper Tithonian-Lower Cretaceous.

DSDP 11-99A-9, core catcher; negative-print from thin-section, $\times 10$.

Figure 4 Irregular contact between pelagic calcilutite (biomicrite with silica-replaced Radiolaria) and chert. The depositional texture, faintly visible in the replacement chert, is the same as in the pelagic calcilutite.

Maiolica, upper Tithonian-Lower Cretaceous, Lombardian Zone, Southern Alps.

Ale di Mendrisio, Monte Generoso, Canton Ticino, Switzerland.

DB 1754; negative-print from thin-section, $\times 10$.

Figure 5 Unconsolidated nannoplankton ooze (cf. Figures 9 and 10) with nodule of hard, lithified chert. The carbonate sediment close to the chert has been lithified: in thin-section it shows essentially the same depositional texture as the chert (Figure 7), that is, of replacement origin. 
Upper Tithonian Valanginian.

DSDP 11-100-1-4, 97-115 cm; sliced core, X0.5.

Figure 6

Contact between silicified sediment and lithified carbonate rock (Figure 5): "dark" spongy aggregates of siliceous material (upper left) replace the carbonate sediment that is mainly composed of nannofossils.

Upper Tithonian-Valanginian.

DSDP 11-100-1-4, 103-107 cm; Stereoscan electron micrograph of fresh broken surface, gold- and carbon-coated, $\times 2000$.

Figure 7 Chert composed of aggregates of finely crystalline silica with ghosts of Radiolaria, preserved as silicafilled spherules.

Upper Tithonian-Valanginian.

DSDP 11-100-1-4, 103-107 cm; thin-section, $\times 12$.

Figure 8 Typical microfacies of Maiolica: calcilutite (biomicrite) containing Calpionella alpina Lorenz and Crassicollaria intermedia (Durand-Delga) (det. F. Allemann).

Base of Vigla Limestone (Maiolica), Upper Tithonian, Ionian Zone, Western Greece.

East of the village of Klissoura, Louros Valley, Epirus, Greece.

DB 1477, thin-section, $\times 50$.

Figures 9,10 Fine sediment of unlithified nannoplankton ooze containing coccoliths, Nannoconus (Figure 9, left) and some unidentified calcite grains.

Upper Tithonian-Valanginian.

DSDP 11-105-1-3, $4-5 \mathrm{~cm}$; Stereoscan electron micrographs of fresh broken surfaces, gold- and carboncoated, $\times 2000$.

Figure 11 Lithified calcilutite of Maiolica facies composed of coccoliths and neomorphically formed calcite.

Base of Maiolica, Upper Tithonian, Umbrian Zone, Central Apennines.

Road from Fiastra to Bolognola, about $2.5 \mathrm{~km}$ northwest of Bolognola, province of Macerata, Italy.

DB 2404, Stereoscan electron micrograph of fresh broken surface, gold- and carbon-coated, $\times 2000$. 
PLATE 11
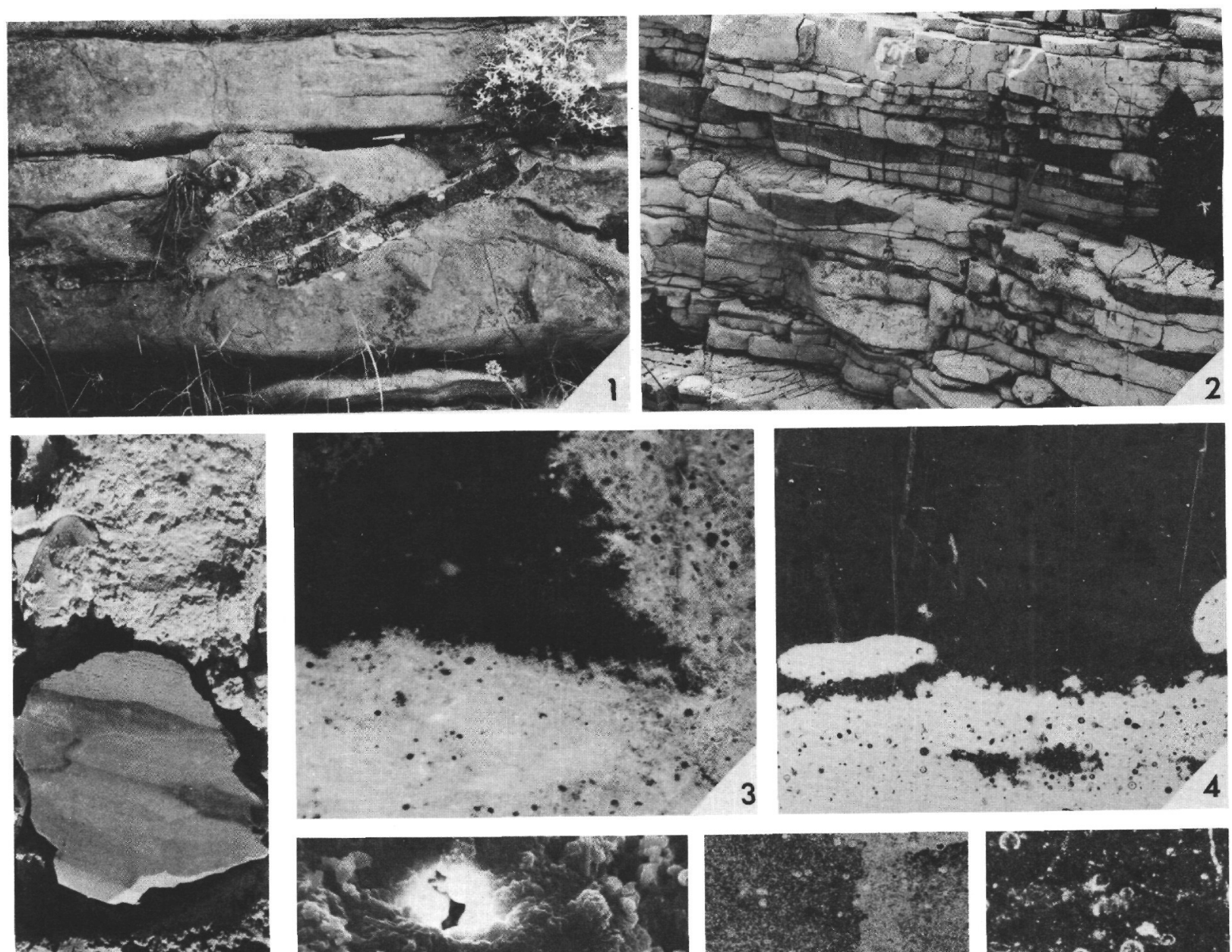

- $x^{3}=2 x+x^{2}$
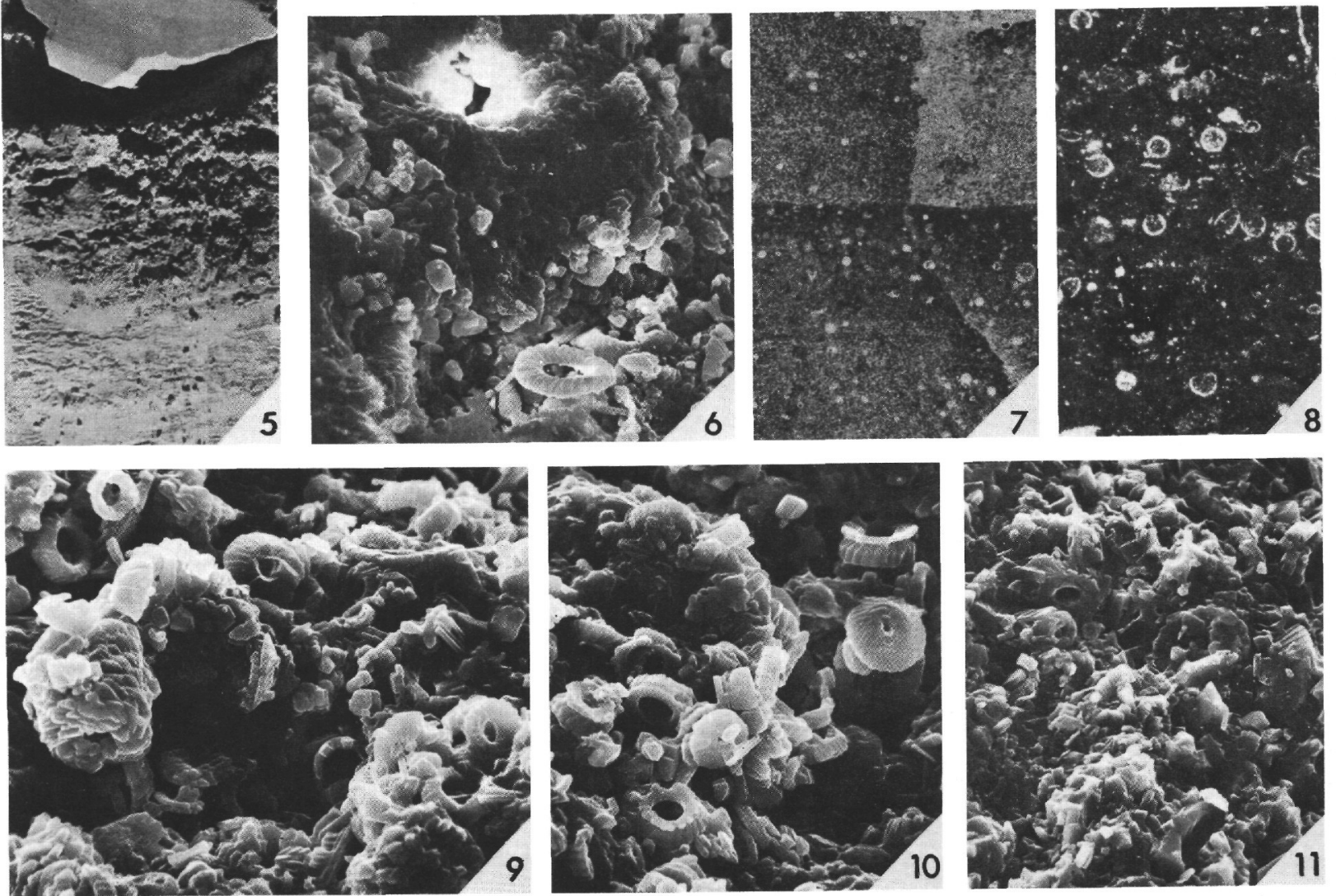
PLATE 12

Monte Sant'Angelo Limestone versus Upper

Cretaceous of Tongue of the Ocean

Figures 1,2, 5 Four to 8 meters-thick conglomerate, intercalated in a sequence of thin-bedded chalky pelagic calcilutites (Plate 14, Figures 1, 3, 5) and of graded and finely laminated calcarenites and calcisiltites (Plate 13, Figures 1, 3, 6). The conglomerate shows large flute-casts at the base (Figure 1) and some grading in the uppermost part; it contains mainly boulders and pebbles of previously lithified shallow-water limestones and fragments of neritic fossils, mainly rudists.

Monte Sant'Angelo Limestone: Upper Cretaceous: Upper Turonian-Coniacian, Eastern Monte Gargano.

Road from Monte Sant'Angelo to Manfredonia, about $1 \mathrm{~km}$ south of Monte Sant'Angelo, province of Foggia, Italy.

Figure 3 Skeletal limestone pebble from conglomerate illustrated in Figure 1,2 and 5. The rock, a biosparite to biosparrudite, contains rounded skeletal fragments, mainly rudists. Partly the skeletal grains are stongly recrystallized; most of them are surrounded by micrite envelopes and many of the small particles have been completely converted into micrite. Some larger (originally aragonitic) shells have been completely dissolved but their micrite envelopes are still preserved. The rock is cemented by an interpartical calcite cement which is also lining the fossil molds; most probably the rock has been lithified in a subaerial or eventually very shallow subtidal environment.

Monte Sant'Angelo limestone, Upper Cretaceous: Upper Turonian-Coniacian, Eastern Monte Gargano.

Road from Monte Sant'Angelo to Manfredonia, about $1 \mathrm{~km}$ south of Monte Sant'Angelo, province of Foggia, Italy.

DB 2547; thin-section, $\times 12$.

Figure 4 Skeletal limestone (biosparite to biosparrudite). As in Figure 3 many of the skeletal limestones are strongly recrystallized and enveloped by a micrite rim; small fragments appear to be completely micritized. The rock is cemented by a calcitic interparticle cement, which also lines the molds of larger dissolved skeletal fragments. The limestone has most probably been cemented subaerially or in a shallow water environment and has been introduced as a lithified pebble into the deeper marine environment of the Tongue of the Ocean (cf. Figures 1, 2, 3, 5).

Upper Cretaceous: Campanian.

DSDP 11-98-15-1, 55-59 cm; thin-section, $\times 12$. 
PLATE 12 - Continued

Figure 6 Skeletal calcarenite (biosparite). The components are essentially the same as in Figure 4, however, there is a greater admixture of larger benthonic foraminifera (Sulcoperculina, Vaughanina). The rock is only loosely cemented by fine drusy calcite, and some echinoderm fragments occur with a syntaxial rim cement similar to the one illustrated by Evamy and Shearman (1969) from a Recent submarine environment.

In contrast to Figure 4 there is no apparent leaching of larger skeletal grains. These observations, together with the presence of planktonic foraminifera, suggest that the components have been transported into the deep-water environment as single grains and that the cement has been formed in the environment of final deposition.

Upper Cretaceous: Campanian.

DSDP 11-98-14-1, $65 \mathrm{~cm}$; thin-section, $\times 20$. 
PLATE 12
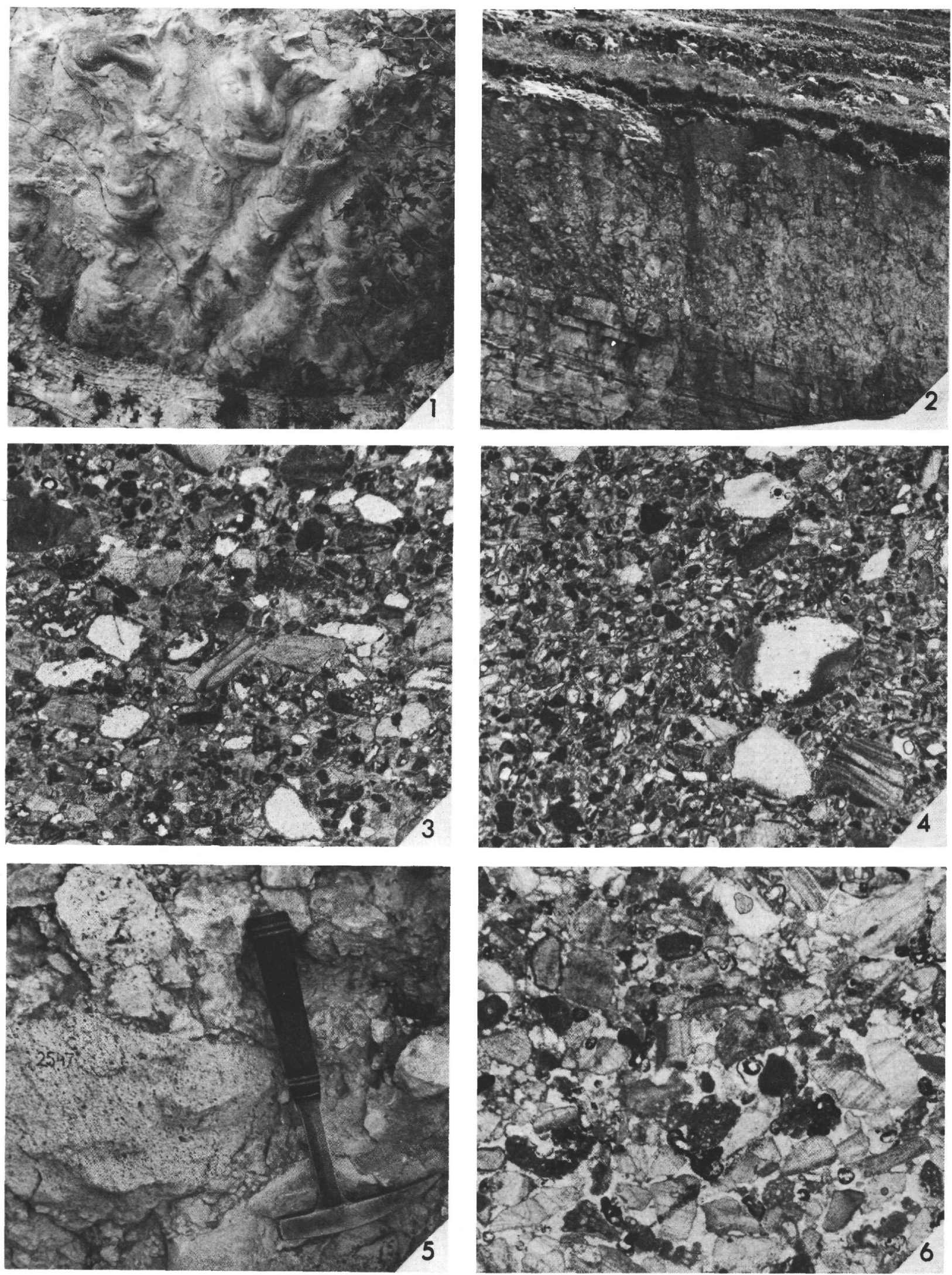
PLATE 13

Monte Sant'Angelo Limestone versus Upper Cretaceous of Tongue of the Ocean

Figure $1 \quad$ Graded skeletal calcarenite (packed biomicrite) with displaced shallow water components, intercalated between pelagic chalky calcilutites (chalky foraminiferal biomicrites; cf. Plate 14, Figure 1, 3, 5).

Monte Sant'Angelo Limestone, Upper Cretaceous: Upper Turonian-Coniacian, Eastern Monte Gargano.

Road from Monte Sant'Angelo to Manfredonia, about $1 \mathrm{~km}$ south of Monte Sant'Angelo, province of Foggia, Italy.

DB 2553; negative-print from thin-section, $\times 3.8$.

Figure 2

Graded and current-laminated fine calcarenite to calcisiltite intercalated between nannoplankton chalks with planktonic foraminifera. The components of the calcarenite are mainly recrystallized bioclastic fragments. In the uppermost part, the sediment has been churned by bottom-dwelling organisms. Occasional dolomite rhombs.

Upper Cretaceous: Campanian.

DSDP 11-98-14-1, 80-82 cm; negative-print from thin-section, $\times 3.8$.

Figure 3 Fine calcarenite to calcisiltite with fine bioclastic material. The sediment that obviously has been redeposited has been strongly churned and burrowed.

Monte Acuto Limestone, Upper Cretaceous: Maastrichtian, Eastern Monte Gargano.

Road from Monte Sant'Angelo to Mattinata, quarry at $\mathrm{km} 6$, province of Foggia, Italy.

DB 2543; negative-print from thin-section, $\times 3.8$.

Figure 4 Laminated fine bioclastic calcarenite to calcisiltite, churned and mixed with pelagic calcilutite (biomicrite with Globotruncana sp.).

Upper Cretaceous: Campanian.

DSDP 11-98-14-1, 80-82 cm; negative-print from thin-section, $\times 3.8$.

Figure 5 Pelagic calcilutite with planktonic foraminifera (Globotruncana sp.) and displaced shallow-water components including clasts of previously lithified shallow-water limestone and more or less recrystallized mollusc fragments, sometimes surrounded by replacement calcite overgrowth. 


\section{PLATE 13 - Continued}

Upper Cretaceous: Campanian.

DSDP 11-98-15-1, $99 \mathrm{~cm}$, negative-print from thinsection, $\times 3.8$.

Figure 6 Redeposited recrystallized skeletal fragments from calcarenite illustrated in Figure 3.

Monte Acuto Limestone, Upper Cretaceous: Maastrichtian.

Road from Monte Sant'Angelo to Mattinata, quarry at $6 \mathrm{~km}$, province of Foggia, Italy.

DB 2543; thin-section, $\times 20$.

Figure 7 Detail of Figure 2. Fine recrystallized bioclastic material overlying pelagic calcilutite.

Upper Cretaceous: Campanian.

DSDP 11-98-14-1, 80-82 cm; thin-section, $\times 20$. 
PLATE 13
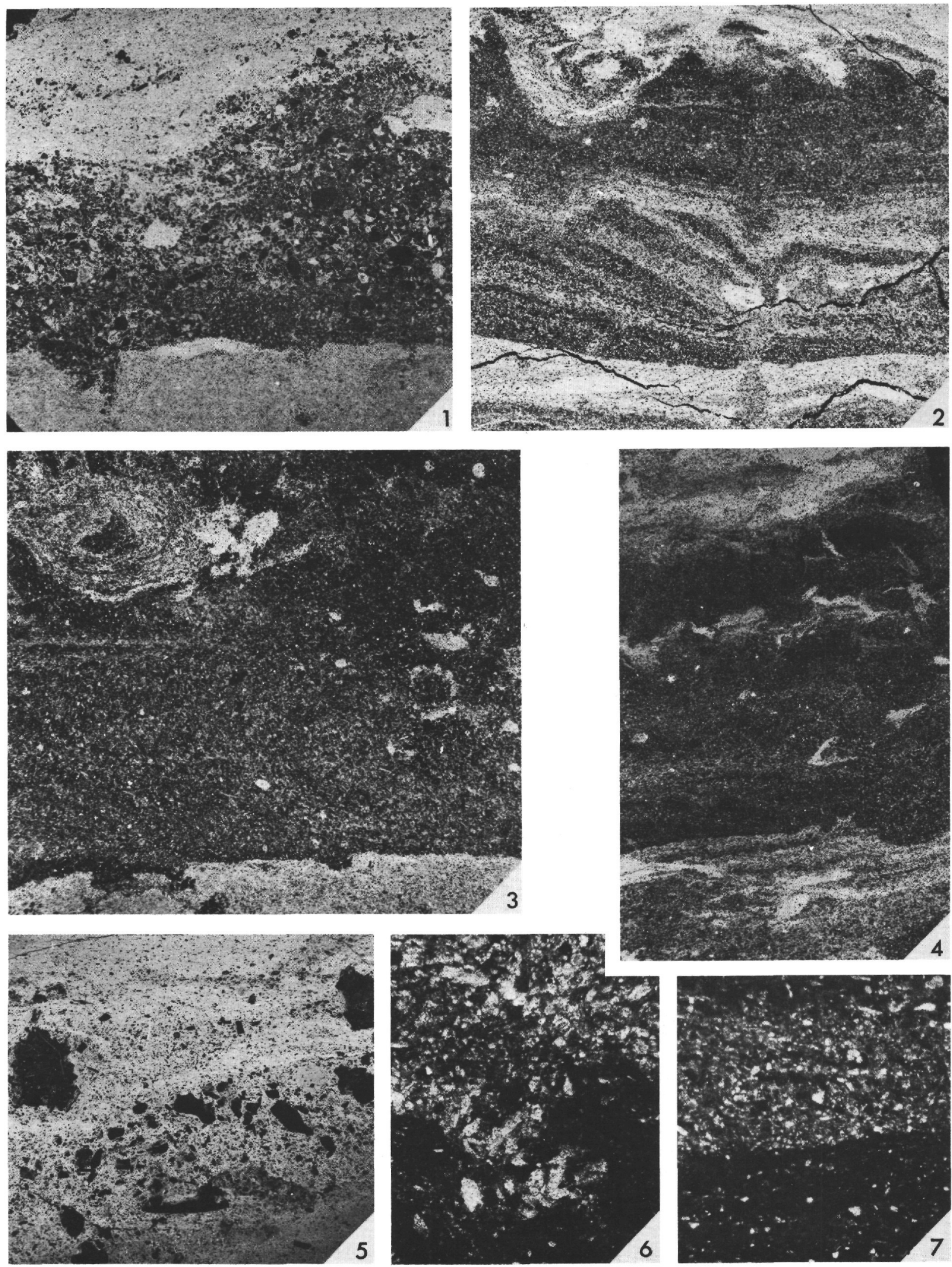
PLATE 14

Monte Sant'Angelo Limestone versus Upper Cretaceous of Tongue of the Ocean

Figure 1 Pelagic sediment of Monte Sant'Angelo Limestone: chalky foraminiferal calcilutite (biomicrite) with Globotruncana linneiana (D'Orbigny) and Globotruncana ex. gr. schneegansi SIGAL-sigali REICHEL (det. M. REICHEL).

Monte Sant'Angelo Limestone, Upper Cretaceous: Upper Turonian-Coniacian. Eastern Monte Gargano (western margin of Ionian zone).

Road from Monte Sant'Angelo to Manfredonia, about $1 \mathrm{~km}$ south of Monte Sant'Angelo, province of Foggia, Italy.

DB 2545; thin-section, $\times 30$.

Figure 2 Pelagic sediment from Tongue of the Ocean: nannoplankton chalk with Globotruncana sp.

Upper Cretaceous: Campanian.

DSDP 11-98-15-1, 96-103 cm; thin-section, $\times 30$.

Figures 3, 5 Fine fraction of pelagic chalky limestones of Monte Sant'Angelo Limestone, composed of well-preserved coccoliths and neomorphically formed calcite.

Monte Sant'Angelo Limestone, Upper Cretaceous: Upper Turonian-Coniacian, Eastern Monte Gargano.

Road from Monte Sant'Angelo to Manfredonia, about $1 \mathrm{~km}$ south of Monte Sant'Angelo, province of Foggia, Italy.

Stereoscan electron micrographs of fresh broken surfaces, gold-coated; 3: DB 2545; X2000; 5: DB $2553 ; \times 5000$.

Figures 4, 6 Fine Sediment of pelagic chalk from Tongue of the Ocean composed almost entirely of calcareous nannoplankton and small unidentified calcite grains.

Upper Cretaceous: Campanian.

DSDP 11-98-14-1，72-74 cm; Stereoscan electron micrographs of fresh broken surfaces, gold- and carbon-coated; $4: \times 2000 ; 6: \times 5000$. 
PLATE 14
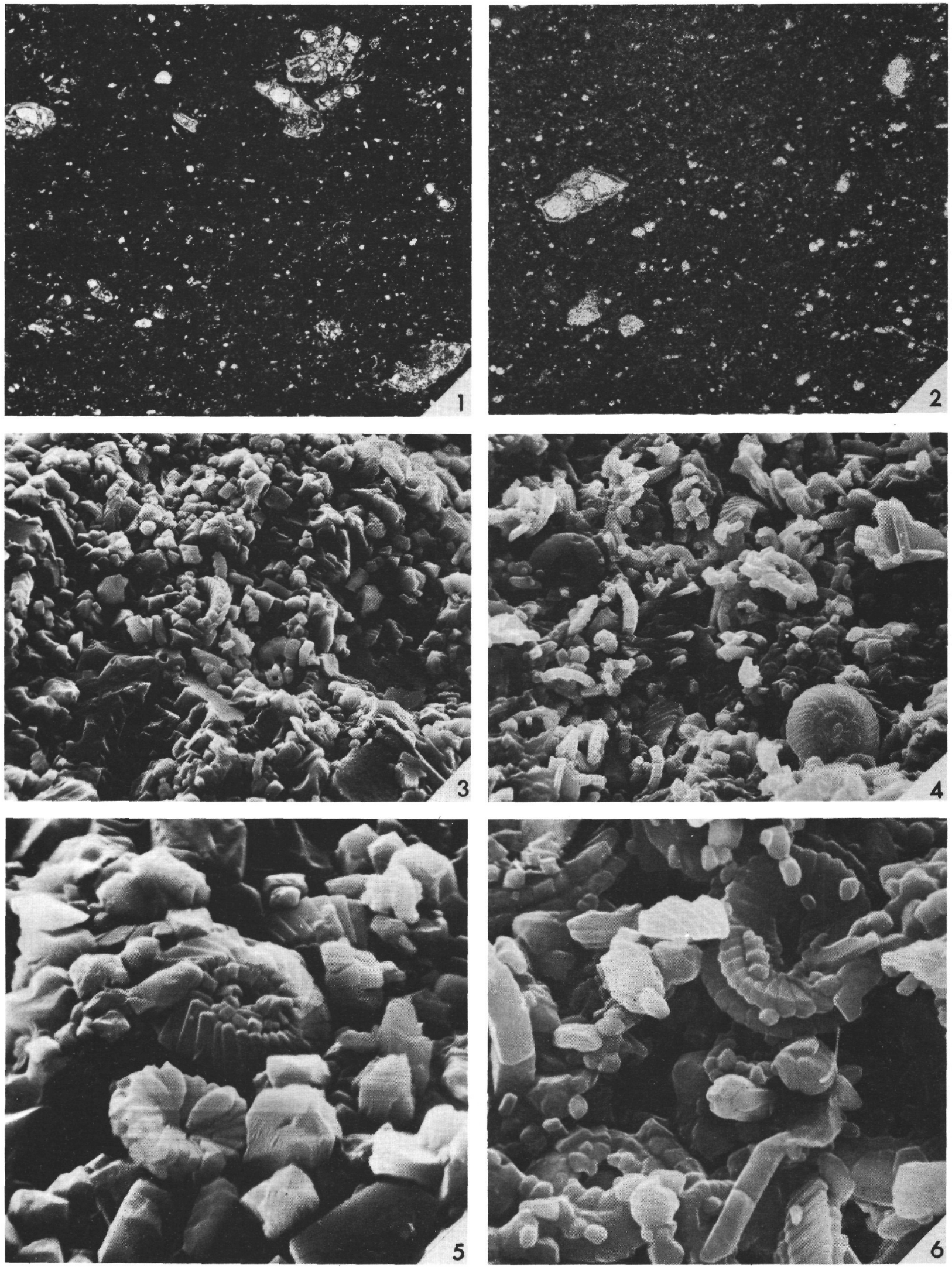